Article

\title{
Discovery of Polyvalent Myovirus (vB_STM-2) Phage as a Natural Antimicrobial System to Lysis and Biofilm Removal of Salmonella Typhimurium Isolates from Various Food Sources
}

\author{
Iman M. A. Abdelhadi ${ }^{1}$, Ahmed R. Sofy ${ }^{2, * \mathbb{C}}$, Ahmed A. Hmed ${ }^{2, *}$, Ehab E. Refaey ${ }^{2}$, Hany E. Soweha ${ }^{1}$ \\ and Mohamed A. Abbas ${ }^{1}$ \\ 1 Botany Department, Faculty of Science, Mansoura University, Mansoura 35516, Egypt; \\ emanhadi@mans.edu.eg (I.M.A.A.); hany49@mans.edu.eg (H.E.S.); mabbas2010@mans.edu.eg (M.A.A.) \\ 2 Botany and Microbiology Department, Faculty of Science, Al-Azhar University, Nasr City, Cairo 11884, Egypt; \\ ehabrefaey@azhar.edu.eg \\ * Correspondence: ahmed_sofy@azhar.edu.eg (A.R.S.); ahmed_hmed@azhar.edu.eg (A.A.H.)
}

Citation: Abdelhadi, I.M.A.; Sofy, A.R.; Hmed, A.A.; Refaey, E.E.; Soweha, H.E.; Abbas, M.A. Discovery of Polyvalent Myovirus (vB_STM-2) Phage as a Natural Antimicrobial System to Lysis and Biofilm Removal of Salmonella Typhimurium Isolates from Various Food Sources. Sustainability 2021, 13, 11602. https:// doi.org/10.3390/su132111602

Academic Editors: Filippo Giarratana and Luca Nalbone

Received: 27 September 2021

Accepted: 11 October 2021

Published: 20 October 2021

Publisher's Note: MDPI stays neutral with regard to jurisdictional claims in published maps and institutional affiliations.

Copyright: (c) 2021 by the authors. Licensee MDPI, Basel, Switzerland. This article is an open access article distributed under the terms and conditions of the Creative Commons Attribution (CC BY) license (https:// creativecommons.org/licenses/by/ $4.0 /)$.

\begin{abstract}
New and natural antimicrobials as an alternative control system are now an urgent need to overcome stubborn bacterial infections. Salmonella Typhimurium has become the most frequent serovar responsible for salmonellosis in humans around the world. The high antimicrobial resistance and biofilm production make this pathogen more dangerous. We aimed to isolate a broad lytic phage to prevent Salmonella infection and reduce its biofilms. Using Salmonella Typhimurium (ST4) as a host, seven phages were isolated, and only three phages showed clear lytic plaques, two members of the Siphoviridae family (vB_STS-1 and vB_STS-3) and one of the Myoviridae family (vB_STM-2). The vB_STM-2 phage was the most potent broad lytic phage, infecting 100\% of tested Salmonella Typhimurium serovars and non-Salmonella strains. Additionally, the vB_STM-2 phage was thermostable at -20 to $55^{\circ} \mathrm{C}$ up to $24 \mathrm{~h}$, while at 65 and $75^{\circ} \mathrm{C}$, a significant $(p<0.05)$ titer reduction was observed after 7 days. Moreover, the phage seemed to be stable at different $\mathrm{pHs}$ (4-11) after one to twelve hours (hrs), while increasing the time made the phage more sensitive to the alkaline medium rather than the acidic medium. Interestingly, the vB_STM-2 phage had the capacity to diminish or eradicate the biofilms of tested Salmonella Typhimurium, e.g., ST-4, ST-19, ST-30, ST-37, ST-45 and ST-49 by $81.2 \%, 76.4 \%, 43.6 \%, 41 \%, 39.8 \%$ and $93.4 \%$, respectively, at a titer concentration of $10^{6} \mathrm{PFU} / \mathrm{mL}$. Eventually, the vB_STM-2 phage showed significant $(p<0.05)$ efficacy in the elimination of Salmonella Typhimurium (ST-4) from contaminated chicken breasts at both storage periods with high titer stability. The Salmonella count showed a severe decline from $7.00 \pm 0.63 \log _{10} \mathrm{CFU} / \mathrm{cm}^{2}$ to $0.88 \pm 0.17 \log ^{10} \mathrm{CFU} / \mathrm{cm}^{2}$ on the seventh day of the shortterm storage, and from $5.13 \pm 0.44 \log _{10} \mathrm{CFU} / \mathrm{cm}^{2}$ to $1.10 \pm 0.12 \log _{10} \mathrm{CFU} / \mathrm{cm}^{2}$ on day 27 of the long-term assay. In both periods, the phage titers remained stable, with insignificant $(p<0.05)$ loss. Therefore, this phage is considered a prime candidate to combat multi-drug-resistant Salmonella Typhimurium and its biofilms.
\end{abstract}

Keywords: Salmonella Typhimurium; multidrug-resistant; bacteriophages; phages; vB_STM-2

\section{Introduction}

Salmonella is a Gram-negative, rod-shaped microorganism that is a member of the well-known bacterial Enterobacteriaceae family [1]. Salmonella can contaminate many types of foods (chicken, livestock, dairy, fruits, and vegetables), increasing the risk of eating contaminated food [2-5]. Many different serovars of Salmonella cause food poisoning, but the most dominant serovar is Salmonella Typhimurium [6].

Nowadays, Salmonella Typhimurium has become the most frequent serovar to be primarily responsible for salmonellosis in humans worldwide [7,8]. However, this serovar was not known until the mid-1990s, and its isolation from humans and animals has only 
increased recently [9]. Salmonellosis is a considerable source of enteric disease for humans in many countries worldwide $[10,11]$. The majority of cases arise from eating contaminated food [12]. Salmonella spp. outlets are responsible for approximately $85 \%$ of foodborne diseases annually, leading to more than 100,000 deaths [10]. In addition, it was the most common pathogen associated with hospitalized patients diagnosed with bloodstream infections in Africa and Asia from 2008 to 2018 [13]. Salmonellosis is characterized by many symptoms, including fever, nausea, vomiting, abdominal cramps, and inflammatory diarrhea. Symptoms occur within 12 to $72 \mathrm{~h}$ and last from 2 to 7 days, with severe infections leading to hospitalization and death [1].

In addition, this bacterium was found to have a great ability to form surface-attached aggregates of communities embedded in extracellular polymeric substances (EPSs), known as biofilm [2]. Biofilm formation by bacteria is undesirable in many fields, including industry, agriculture, and medicine [14]. In short, biofilm increases the survival rate of bacteria from 1 to 1000 times and may weakens the effect of antibiotics or prevent their effects completely $[15,16]$. Antibiotics are the conventional control strategies to eliminate Salmonella serovars [1], but later resistance to these traditional antibiotics has emerged, which has led to the emergence of multidrug-resistant Salmonella spp. [17]. Therefore, it was necessary to find a promising alternative to control such resistant infections. Bacteriophages are natural bacteria viruses used as alternative antimicrobial agents (lytic type) to counter such multidrug-resistant bacteria [18].

Phages are highly capable against bacteria contaminating food products [19,20]. Due to their defense mechanisms and high diversity, many studies have reported the isolation and successful use of phages in the control of Salmonella [21-23]. Many previous studies have determined that Salmonella phages of a wide host range could control Salmonella, including S. enteritidis or Salmonella Typhimurium [24]. Although phages are usually species-specific [25], some polyvalent phages have been observed, especially among the phages of the Enterobacteriaceae family $[26,27]$. Phages with polyvalent behavior can infect strains from different genera or species, which is preferable to others [28].

Bacteriophages have been employed to control Salmonella in many foods, such as chicken [29,30], beef [31], pork [32], fruits [33], and dairy products [34].

This study aimed to isolate a lytic polyvalent bacteriophage to control multiple drugresistant Salmonella Typhimurium (the most widely spread serovar) and combat its biofilm.

\section{Materials and Methods}

\subsection{Salmonella Typhimurium Isolates Sources in the Study}

A total of 23 Salmonella strains presenting a Typhimurium serovar previously isolated from food sources according to Silliker and Taylor [35] and ISO [36] were used in this study (Table 1). In addition, Salmonella Typhimurium (ST-4) was used as a lawn strain for phage isolation, propagation, and purification. All Salmonella used were previously isolated in the plant viruses and bacteriophage Lab of Botany and Microbiology Department, Faculty of Science at Al-Azhar University (Cairo, Egypt). Salmonella isolates were stored in 15\% glycerol at $-80{ }^{\circ} \mathrm{C}$ as testing stocks. For fresh culture, a colony formed by streaking on Tryptone Soya Agar (TSA) obtained from Oxoid (Hampshire, UK) was developed in $5 \mathrm{~mL}$ of Tryptone Soya Broth (TSB) also obtained from Oxoid, and left in the incubator for 16-18 h at $37^{\circ} \mathrm{C}$.

Table 1. Source, antibiotic-resistance profile, and biofilm characteristics of Salmonella serovars used in this study. Salmonella Typhimurium (ST-4) was used for phage isolation and propagation. All serovars were involved in the host range determination.

\begin{tabular}{|c|c|c|c|c|c|c|}
\hline Serovars & Isolate ID & Source & $\begin{array}{c}\text { Antibiotic- } \\
\text { Resistance } \\
\text { Profile }\end{array}$ & $\begin{array}{l}\text { Optical Density } \\
\text { of Cell Growth } \\
\left(\mathrm{OD}_{620} \mathrm{~nm}\right)\end{array}$ & $\begin{array}{c}\text { Optical Density } \\
\text { of Biofilm } \\
\left(\mathrm{OD}_{570} \mathrm{~nm}\right)\end{array}$ & Interpretation \\
\hline $\begin{array}{c}\text { Salmonella } \\
\text { Typhimurium }\end{array}$ & ST-4 & $\begin{array}{l}\text { Chicken } \\
\text { (Egypt) }\end{array}$ & Resistant & 1.847 & 0.947 & Strong \\
\hline $\begin{array}{c}\text { Salmonella } \\
\text { Typhimurium }\end{array}$ & ST-7 & $\begin{array}{l}\text { Chicken } \\
\text { (Egypt) }\end{array}$ & Resistant & 0.998 & 0.411 & Moderate \\
\hline
\end{tabular}


Table 1. Cont.

\begin{tabular}{|c|c|c|c|c|c|c|}
\hline Serovars & Isolate ID & Source & $\begin{array}{l}\text { Antibiotic- } \\
\text { Resistance } \\
\text { Profile }\end{array}$ & $\begin{array}{l}\text { Optical Density } \\
\text { of Cell Growth } \\
\left(\mathrm{OD}_{620} \mathrm{~nm}\right)\end{array}$ & $\begin{array}{c}\text { Optical Density } \\
\text { of Biofilm } \\
\left(\mathrm{OD}_{570} \mathrm{~nm}\right)\end{array}$ & Interpretation \\
\hline $\begin{array}{c}\text { Salmonella } \\
\text { Typhimurium }\end{array}$ & ST-9 & $\begin{array}{l}\text { Chicken } \\
\text { (Egypt) }\end{array}$ & Resistant & 0.876 & 0.563 & Moderate \\
\hline $\begin{array}{c}\text { Salmonella } \\
\text { Typhimurium }\end{array}$ & ST-14 & $\begin{array}{l}\text { Bovine } \\
\text { (Egypt) }\end{array}$ & Resistant & 1.022 & 0.744 & Strong \\
\hline $\begin{array}{c}\text { Salmonella } \\
\text { Typhimurium }\end{array}$ & ST-16 & $\begin{array}{l}\text { Bovine } \\
\text { (Egypt) }\end{array}$ & Resistant & 0.773 & 0.117 & Weak \\
\hline $\begin{array}{c}\text { Salmonella } \\
\text { Typhimurium }\end{array}$ & ST-19 & $\begin{array}{l}\text { Bovine } \\
\text { (Egypt) }\end{array}$ & Resistant & 1.977 & 1.081 & Strong \\
\hline $\begin{array}{c}\text { Salmonella } \\
\text { Typhimurium }\end{array}$ & ST-21 & $\begin{array}{l}\text { Dairy } \\
\text { products } \\
\text { (Egypt) }\end{array}$ & Resistant & 0.712 & 0.108 & Weak \\
\hline $\begin{array}{c}\text { Salmonella } \\
\text { Typhimurium }\end{array}$ & ST-22 & $\begin{array}{l}\text { Dairy } \\
\text { products } \\
\text { (Egypt) }\end{array}$ & Resistant & 1.446 & 0.742 & Strong \\
\hline $\begin{array}{c}\text { Salmonella } \\
\text { Typhimurium }\end{array}$ & ST-27 & $\begin{array}{l}\text { Dairy } \\
\text { products } \\
\text { (Egypt) }\end{array}$ & Resistant & 1.784 & 0.748 & Strong \\
\hline $\begin{array}{c}\text { Salmonella } \\
\text { Typhimurium }\end{array}$ & ST-30 & $\begin{array}{l}\text { Chicken } \\
\text { (Egypt) }\end{array}$ & Resistant & 1.709 & 0.904 & Strong \\
\hline $\begin{array}{c}\text { Salmonella } \\
\text { Typhimurium }\end{array}$ & ST-33 & $\begin{array}{l}\text { Chicken } \\
\text { (Egypt) }\end{array}$ & Resistant & 0.993 & 0.321 & Moderate \\
\hline $\begin{array}{c}\text { Salmonella } \\
\text { Typhimurium }\end{array}$ & ST-35 & $\begin{array}{l}\text { Chicken } \\
\text { (Egypt }\end{array}$ & Resistant & 1.003 & 0.411 & Moderate \\
\hline $\begin{array}{c}\text { Salmonella } \\
\text { Typhimurium }\end{array}$ & ST-36 & $\begin{array}{l}\text { Chicken } \\
\text { (Egypt) }\end{array}$ & Resistant & 0.878 & 0.103 & Weak \\
\hline $\begin{array}{c}\text { Salmonella } \\
\text { Typhimurium }\end{array}$ & ST-37 & $\begin{array}{l}\text { Chicken } \\
\text { (Egypt) }\end{array}$ & Resistant & 2.047 & 1.105 & Strong \\
\hline $\begin{array}{c}\text { Salmonella } \\
\text { Typhimurium }\end{array}$ & ST-38 & $\begin{array}{l}\text { Chicken } \\
\text { (Egypt) }\end{array}$ & Resistant & 0.788 & 0.119 & Weak \\
\hline $\begin{array}{c}\text { Salmonella } \\
\text { Typhimurium }\end{array}$ & ST-41 & $\begin{array}{l}\text { Bovine } \\
\text { (Egypt) }\end{array}$ & Resistant & 0.936 & 0.366 & Moderate \\
\hline $\begin{array}{c}\text { Salmonella } \\
\text { Typhimurium }\end{array}$ & ST-43 & $\begin{array}{l}\text { Bovine } \\
\text { (Egypt) }\end{array}$ & Resistant & 1.171 & 0.773 & Strong \\
\hline $\begin{array}{c}\text { Salmonella } \\
\text { Typhimurium }\end{array}$ & ST-45 & $\begin{array}{l}\text { Bovine } \\
\text { (Egypt) }\end{array}$ & Resistant & 1.664 & 0.817 & Strong \\
\hline $\begin{array}{c}\text { Salmonella } \\
\text { Typhimurium }\end{array}$ & ST-47 & $\begin{array}{l}\text { Bovine } \\
\text { (Egypt) }\end{array}$ & Resistant & 0.899 & 0.541 & Moderate \\
\hline $\begin{array}{c}\text { Salmonella } \\
\text { Typhimurium }\end{array}$ & ST-49 & $\begin{array}{l}\text { Bovine } \\
\text { (Egypt) }\end{array}$ & Resistant & 1.811 & 0.927 & Strong \\
\hline $\begin{array}{c}\text { Salmonella } \\
\text { Typhimurium }\end{array}$ & ST-53 & $\begin{array}{l}\text { Dairy } \\
\text { products } \\
\text { (Egypt) }\end{array}$ & Resistant & 0.659 & 0.173 & Weak \\
\hline $\begin{array}{c}\text { Salmonella } \\
\text { Typhimurium }\end{array}$ & ST-55 & $\begin{array}{l}\text { Dairy } \\
\text { products } \\
\text { (Egypt) }\end{array}$ & Resistant & 0.744 & 0.196 & Weak \\
\hline $\begin{array}{c}\text { Salmonella } \\
\text { Typhimurium }\end{array}$ & ST-56 & $\begin{array}{l}\text { Dairy } \\
\text { products } \\
\text { (Egypt) }\end{array}$ & Resistant & 1.022 & 0.511 & Moderate \\
\hline
\end{tabular}




\subsection{Inoculums Preparation of Isolates}

Salmonella strains were cultured into a TSB medium and incubated at $37^{\circ} \mathrm{C}$ until a midlogarithmic phase. The cells concentration was adjusted in $\mathrm{CFU} / \mathrm{mL}$ against $0.5 \mathrm{McF}$ arland turbidity standard $\left(1.5 \times 10^{8} \mathrm{CFU} / \mathrm{mL}\right)$ [37].

\subsection{Confirm the Identification of the Salmonella Typhimurium Used}

Confirmation of Salmonella Typhimurium was performed in two major steps. The first step involved the morphological [38], biochemical [39,40], and serological (slide agglutination test) [41,42] characteristics. The second step, Biomerieux VITEK 2 identification system $[27,28]$, automatically confirmed Salmonella Typhimurium.

\subsection{Statuses of Antibiotic-Resistant Profiles of Salmonella Typhimurium Used}

A total of 23 Salmonella strains presenting Typhimurium serovar were tested to determine the antibiotic-resistant profiles using disc diffusion assay as described by Bauer [43] This assay was performed with the following tested antibiotics (the most widely used antibiotics in human medicine in Egypt): streptomycin $(10 \mu \mathrm{g})$, kanamycin $(30 \mathrm{mcg})$, flucloxacillin $(5 \mathrm{mcg})$, tetracycline $(30 \mathrm{mcg})$, levofloxacin $(5 \mathrm{mcg})$, tobramycin $(10 \mathrm{mcg})$, aztreonam (1 mcg), oxacillin ( $1 \mathrm{mcg})$, rifamycin $(30 \mathrm{mcg})$, erythromycin $(15 \mathrm{mcg})$, amoxicillin/clavulanic acid amc $(20 \mu \mathrm{g})$, clindamycin $(2 \mathrm{mcg})$, gentamicin $(10 \mathrm{mcg})$, cephradine $(30 \mathrm{mcg})$, ciprofloxacin $(5 \mathrm{mcg})$, and ampicillin $(10 \mathrm{mcg})$ which were obtained from ElGomhouria co. for trading chemicals and medical appliances (Cairo, Egypt). The resistance or sensitivity of the tested bacteria to the antibiotics used was determined by measuring the growth inhibitory zone around each antibiotic disc after $24 \mathrm{~h}$ of incubation at $37^{\circ} \mathrm{C}$. The obtained results were designated as $\mathrm{S}$ (sensitive), I (intermediate sensitive), and $\mathrm{R}$ (resistant) based on the standardized protocols by the National Committee for Clinical Laboratory Standards (NCCLS) [44].

\subsection{Biofilm Forming Capacity of Salmonella Typhimurium Isolates}

The tissue culture plate method described by Stepanović et al. [45] was used for the qualitative assay of biofilm formation activity of all 23 Salmonella Typhimurium isolates. In this assay, biofilm formation was evaluated in 96-well tissue culture polystyrene plates, with flat bottoms and lids (Sigma-Aldrich, St. Louis, MO, USA). In total, $200 \mu \mathrm{L}$ of TSB medium supplemented with $0.25 \%$ glucose was added into each well, plus $20 \mu \mathrm{L}$ of $10^{5} \mathrm{CFU} / \mathrm{mL}$ bacterial suspension. After overnight incubation at $37^{\circ} \mathrm{C}$, the plates were aspirated and washed using phosphate-buffered saline (PBS). The adsorbed bacteria were fixed by $95 \%$ ethanol to the polystyrene wells and then stained using crystal violet $(0.1 \%)$ after removing the ethanol by washing. The dye was solubilized in $1 \% w / v$ SDS, and the optical densities were measured at O.D.570 $\mathrm{nm}$ photometrically by an ELISA reader (Sunrise ${ }^{\mathrm{TM}}-\mathrm{TECAN}$, Männedorf, Switzerland) at the Botany and Microbiology Department, Faculty of Science, Al-Azhar University, Cairo, Egypt. The assay was performed in triplicate. The formed biofilm was described as low, moderate, or strong, depending on the interpretation of Stepanović et al. [45].

\subsection{Isolation and Purification of Salmonella Typhimurium Phages}

2.6.1. Isolation Source

Twenty milliliters $(20 \mathrm{~mL})$ of sewage water (9 different samples) was obtained from Kafr El-Sheikh (N $30^{\circ} 56^{\prime} 45^{\prime \prime}$ E $31^{\circ} 06^{\prime} 42^{\prime \prime}$ ) governorate, Egypt.

\subsubsection{Isolation and Enrichment}

For the isolation of Salmonella Typhimurium phages, the method described by Bibi et al. [46] was used; 10-mL of centrifuged sewage water (supernatant) was mixed with an equal volume of TSB media (Difco ${ }^{\mathrm{TM}}, \mathrm{BD}, \mathrm{USA}$ ). At the mid-logarithmic phase of the host bacteria (Salmonella Typhimurium; ST-4), $100 \mu \mathrm{L}$ was added to the mixture of sewage water and media, followed by overnight incubation (shaking at $270 \mathrm{rpm}$ ) at $37^{\circ} \mathrm{C}$. At $7000(\times g)$, 
the previous mixture after incubation was centrifuged for $10 \mathrm{~min}$.; the pellet was discarded, and through a sterile filter $(0.45-\mu \mathrm{m})$, the supernatant was filtered and stored at $4{ }^{\circ} \mathrm{C}$ in a clean, sterile flask.

\subsection{Phage Detection \\ Spot-Assay Technique}

According to Capra et al. [47], a spot-test assay was performed. The overlay (4 mL of TSB supplemented with $0.7 \%$ agar) layer was prepared. In total, $100 \mu \mathrm{L}$ of $24 \mathrm{~h}$ incubated bacterial culture (host bacterium) was inoculated into the previous layer (soft layer). The soft layer was poured over previously prepared solid trypticase soy agar (TSA) plates (overlay layer). Then, $10 \mu \mathrm{L}$ from each enriched sample was spotted over the plates and incubated at $37^{\circ} \mathrm{C}$ for $24 \mathrm{~h}$. After the incubation period, phage activity appeared in the form of zones of complete or partial lysis on the soft layer. In CM phage buffer $(0.73 \mathrm{~g} / \mathrm{L}$ $\mathrm{CaC}_{12} .2 \mathrm{H}_{2} \mathrm{O}: 2.5 \mathrm{~g} / \mathrm{L} \mathrm{MgSO}_{4}$. $7 \mathrm{H}_{2} \mathrm{O} ; 0.05 \mathrm{~g} / \mathrm{L}$ gelatin; $6 \mathrm{~mL} / \mathrm{L} 1 \mathrm{M}$ Tris buffer; $\mathrm{pH}$ 7.2), lysis zones were relocated separately under aseptic conditions.

Plaque Assay Technique

The double-layer agar method was performed by Sangha et al. [48] to assay phages' plaque formation. In TSB, ten-fold serial dilutions for phage lysate were performed. Then, $100 \mu \mathrm{L}$ from each dilution of phage lysate was inoculated to $100 \mu \mathrm{L}$ from the overnight host's culture $\left(10^{9} \mathrm{CFU} / \mathrm{mL}\right)$ and left in an incubator for 10 to $15 \mathrm{~min}$. Next, the previous mixture was mixed gently, placed in a 4-mL soft agar medium, and then poured over the TSA plates. Afterward, the plates were incubated overnight at $37^{\circ} \mathrm{C}$, resulting in different plaques, whose sizes and shapes were quantified.

Purification, Propagation, and Titration

All these assays were performed by the double overlay method following Sangha et al. [48]. Using a sterile wire loop, an individual plaque was picked and then transferred to TSB inoculated with the bacterial host used in phage isolation (Salmonella Typhimurium; ST-4). To confirm the purity of the phage, the double overlay method was conducted at least three times. Regarding phage propagation, $100 \mu \mathrm{L}$ of phage was added to $100 \mu \mathrm{L}$ of bacterial lawn in TSB medium, followed by overnight incubation at $37^{\circ} \mathrm{C}$. Ten overlay agar plates were prepared for each isolate phage, and $3 \mathrm{~mL}$ of $\mathrm{CM}$ buffer was spread over each plate. In $50 \mathrm{~mL}$ clean, sterile tubes, the upper area of the soft layer in the plates was scribbled and transferred. The collected tubes were vortexed (Vortex-Genie-2; Inc., Bohemia, NY, USA) for $5 \mathrm{~min}$ after being left for $15 \mathrm{~min}$. Tubes were centrifugated $(7000 \times \mathrm{g} / 15 \mathrm{~min})$ at $4{ }^{\circ} \mathrm{C}$, the supernatant was filtered and then transferred into a clean, sterile tube to keep at $4{ }^{\circ} \mathrm{C}$. A ten-fold serial dilution of the phage suspension was performed to calculate phage titers, and the resulting plaques were counted by the double overlay method, as previously explained.

Host Range Study

Using spot-testing, the host spectra of all isolated phages were studied per Capra et al. [47]. This assay was conducted on the bacterial isolates listed in Table 1, in addition to 13 other strains. The strains other than Salmonella included 5 of Pseudomonas aeruginosa (clinical and food sources), 3 of Staphylococcus aureus (food sources), 4 of Escherichia coli (clinical isolates), and 1 of Klebsiella pneumoniae (clinical source). The soft agar layer was inoculated with $100 \mu \mathrm{L}$ fresh cultured strain and $\left(1.5 \times 10^{9} \mathrm{CFU} / \mathrm{mL}\right)$ poured onto the overlay layer (TSA). After solidification, the phage suspension $\left(1 \times 10^{7} \mathrm{PFU} / \mathrm{mL}\right)$ was dropped on the soft layer and then incubated for $24 \mathrm{~h}$ at $37^{\circ} \mathrm{C}$. Areas of spot-lysis on the tested strain were considered phage sensitive. The potent phage that showed the broadest host range in the spot test was confirmed by the efficiency of the plating (EOP) method, according to Mirzaei and Nilsson [49]. The test results of the EOP are interpreted in different patterns, namely, inefficient EOP $<0.001$; low efficiency EOP from 0.001 to $<0.2$; 
moderate efficiency EOP from 0.2 to $<0.5$; and high efficiency EOP from 0.5 to 1.0. The experiments were performed in triplicates with standard deviation $( \pm \mathrm{SD})$.

Transmission Electron Microscopy (TEM)

In total, $1 \mathrm{~mL}$ of purified high titer stock phages was centrifuged for $1 \mathrm{~h} / 16,000 \times g$ at $4{ }^{\circ} \mathrm{C}$, the supernatant was discarded, and the pellet was resuspended in $\mathrm{CM}$ phage buffer $(20 \mu \mathrm{L})$. On the carbon grids ( 200 mesh) coated with formvar, $5 \mu \mathrm{L}$ of phage suspension was added and fixed for $2 \mathrm{~min}$. The examined phages were negatively stained (30 s) by $2 \%$ uranyl acetate, and the excess dye was removed by paper [50]. At the Regional Center for Mycology and Biotechnology, Al-Azhar University, Cairo, Egypt, the samples were examined by electron microscopy (Model Beckman 1010) operated at $60 \mathrm{KV}$ [51].

Thermo and pH Stability of vB_STM-2 Phage

At different times $(1,2,4,12,24$, and 7 days), the stability of the vB_STM-2 phage was checked at different temperatures (e.g., $-20,4,25,37,55,65$, and $75^{\circ} \mathrm{C}$ ) as well as $\mathrm{pH}$ levels $(4,7,9$, and 11). Both experiments were carried out per Philipson et al. [52] and Jamalludeen et al. [53] for temperature and $\mathrm{pH}$ stability. The initial titer of the phage was $7 \log _{10}$, and any titer changes were detected during the experiments using the double-layer agar method of Sangha et al. [48]. Assays were performed in triplicate with a long standard deviation $( \pm \mathrm{SD})$.

Biofilm Removal Activity of the vB_STM-2 Phage

The antibiofilm activity of the $\mathrm{vB}$ _STM-2 phage against the strongest biofilm-producing Salmonella Typhimurium listed in Table 1 was measured. Coincidentally, 6 isolates with codes ST-4, ST-19, ST-30, ST-37, ST-45, and ST-49 were the strongest and were derived from a meat source, i.e., chicken or bovine. According to Bekir et al. [54], the test was performed using 96-well tissue culture polystyrene plates with a flat bottom and a lid (Sigma-Aldrich, St. Louis, MO, USA). Then, $20 \mu \mathrm{L}$ of tested bacterial culture (at mid-logarithmic phase) $\left(2 \times 10^{6} \mathrm{CFU} / \mathrm{mL}\right)$ was inoculated into $200 \mu \mathrm{L}$ TSB medium supplemented with $0.25 \%$ glucose in the plate wells. In some specific wells of the plate, $100 \mu \mathrm{L}$ phage suspension $\left(1 \times 10^{6} \mathrm{PFU} / \mathrm{mL}\right.$ ) was added and mixed well (wells of anti-biofilm). Thus, there were wells without phage addition in the plate, which contained bacteria and media (wells of biofilm), and wells to which we did not add the phage or bacteria (wells of negative control). Biofilm reduction by the phage was calculated according to Else et al. [55] and Kostaki et al. [56] by the following equation:

$$
[(C-B)-(T-B)] /[(C-B)] \times 100
$$

where $\mathrm{C}=$ refers to the optical density $\left(\mathrm{OD}_{620} \mathrm{~nm}\right)$ of the control result, $\mathrm{B}=$ refers to the optical density $\left(\mathrm{OD}_{620} \mathrm{~nm}\right)$ of the blank (TSB), and $\mathrm{T}=$ refers to the optical density $\left(\mathrm{OD}_{570} \mathrm{~nm}\right)$ of phage-treated wells.

\subsection{Bacterial Challenge Measurements In Broth Medium (Culture Clearing)}

Tests of the bacterial challenge were carried out to detect the activity of the vB_STM-2 phage in confronting Salmonella in a liquid medium. In brief, 3 clean flasks, each with $100 \mathrm{~mL}$ sterile TSB, were prepared. First, $1 \mathrm{~mL}\left(6 \log _{10} \mathrm{CFU} / \mathrm{mL}\right)$ fresh Salmonella Typhimurium (ST-4) culture was inoculated into only 2 flasks of the three, while the latter remained unchanged. Next, $1 \mathrm{~mL}$ phage $\left(8 \log _{10} \mathrm{PFU} / \mathrm{mL}\right)$ was injected into one of the flasks implanted with bacteria (treated flask), while the other implanted one was injected with sterile distilled water (positive control flask). The flasks containing the TSB medium remained a negative control. Finally, the three flasks were placed overnight in an incubator shaker $(220 \mathrm{rpm})$ at $37{ }^{\circ} \mathrm{C}$, with $2 \mathrm{~mL}$ of each flask taken at $0,1,3,6,12$, and $24 \mathrm{~h}$ to determine the count of Salmonella. For accuracy comparison, $1 \mathrm{~mL}$ was examined by spectrophotometry $\left(\mathrm{OD}_{620} \mathrm{~nm}\right)$, while the other was examined by counting $\left(\log _{10}\right)$ Salmonella on TSA plates. The tests were performed in triplicate with standard deviation $( \pm \mathrm{SD})$. 


\subsection{Preparation of the Food Sample Used in the Study}

The first step: in a local supermarket, chicken breasts (used as a food model) with a recent production date were purchased, placed in sterile bags, and then transferred in an icebox to the laboratory to carry out the experiment. Using a sterile meat cutting board in the laminar flow, chicken breasts were sliced into small squares $(2 \times 2 \mathrm{~cm})$ with a clean, sterile knife [57]. These squares were sterilized for $3 \mathrm{~h}$ with $70 \%$ ethanol, washed three times with sterile water, and then left to dry for half an hour. After drying, all squares were examined on TSA plates according to FDA [58]; any squares that showed microbial growth were excluded, and the remaining squares were used.

The second step: the used squares were divided into 2 sections; each section had 3 groups of squares. The first section was prepared for the short-term experiment ( 7 days) as follows: in two of the three groups, Salmonella Typhimurium culture (ST-4) was inoculated $\left(7 \log _{10} \mathrm{CFU} / \mathrm{cm}^{2}\right)$, while the third remained the same. The second section was prepared for the long-term experiment (27 days) as follows: similar to the above, Salmonella Typhimurium culture (ST-4) was inoculated $\left(6 \log _{10} \mathrm{CFU} / \mathrm{cm}^{2}\right)$ in 2 groups, while the other remained the same. The two experiments were performed in triplicate with standard deviation $( \pm \mathrm{SD})$.

\subsection{Effectiveness and Stability of the vB_STM-2 Phage in Food Preservation}

Short-term assay: one of the two groups inoculated with bacteria from the first section of groups was treated with a phage suspension $\left(8 \log _{10} \mathrm{PFU} / \mathrm{cm}^{2}\right)$ (inoculated, treated group), while the second inoculated group remained without treatment (inoculated, untreated group). The remaining uninfected third group was not treated (non-inoculated, un-treated group). Squares of the three groups were placed independently in sterile Petri dishes, covered with sterile plastic rubber, and kept at $4{ }^{\circ} \mathrm{C}$. Colonies of Salmonella $\left(\log _{10} \mathrm{CFU} / \mathrm{cm}^{2}\right)$ and titers of phage (PFU/ $\left.\mathrm{cm}^{2}\right)$ were counted at days $0,1,2,4$, and 7 of the storage period to judge the ability of the phage to inhibit Salmonella, as well as its stability.

Long-term assay: as in the previous experiment, groups of chicken breasts were treated in the same way here but were kept for 27 days at $-20^{\circ} \mathrm{C}$. In addition, both the counting of the Salmonella colonies and titers of the phage were carried out at days 0, 2, 7, 14,21 , and 27 of the storage period.

\subsection{Recovery of Inoculated Salmonella from Food}

On the days specified in both experiments to check the chicken breast squares, they were taken out and left for appropriately an hour at $37^{\circ} \mathrm{C}$. Each sample was placed into a sterile bag containing $2 \mathrm{~mL}$ sterile phosphate-buffered saline (PBS). The sample was homogenized by a sterile flattened rod and vortexed [59]. The homogenized sample was centrifuged for $10 \mathrm{~min}$ at $3000 \times g$ [60], the supernatant was discarded to avoid plating the bacteriophage. A pellet containing precipitated bacteria was mixed with sterile peptone water (PW) and then serially diluted (10-fold). Then, $100 \mu \mathrm{L}$ was spread over TSA and xylose lysine desoxycholate (XLD; Oxoid) agar plates from each dilution. For a day or two, the plates were incubated at $37^{\circ} \mathrm{C}$. After incubation, the suspected Salmonella colonies were counted, and the biochemical/serological tests were performed [35,41].

\subsection{Statistical Analysis}

All experiments were performed in triplicate with standard deviation $( \pm \mathrm{SD})$, where three independent samples/assays were taken in each replicate. For bacteria and the phage, the data were converted into $\log _{10}$ form. Statistical Package for the Social Sciences version 26.00 (SPSS) was the statistical program used at a probability level of 0.05 . One-way ANOVA was used to achieve quantitative analyses with the least significant difference (LSD) test variance analysis. Graphs were produced with GraphPad Prism 8. 


\section{Results}

\subsection{Bacterial Isolates, Identification, Antibiotic-Resistant and Biofilm Behavior}

Suspect Salmonella Typhimurium colonies were 1-2 $\mathrm{mm}$ in diameter with an offwhite color and circular shape in the TSA plates. The colonies appeared to be red with black centers in some, with 2-3 in some diameter on the XLD plates. The biochemically identified cells with the oxidase, Indole, and Vogues-Proskauer (VP) tests were Gramnegative type rods, with negative interactions. The biochemical tests that showed positive results were urease, methyl red (MR), and a reduction of nitrate to nitrite. The slide agglutination test used to determine the serotype level of Salmonella showed that all isolates were given a positive reaction with both antisera of $\mathrm{O}($ poly $\mathrm{O})$ and polyvalent $\mathrm{H}$ (poly H). In the affirmative identification by the Biomerieux VITEK 2 system, the results of the 23 isolates were all Salmonella Typhimurium. The antibiotic sensitivity profile test of Salmonella Typhimurium showed at least six antibiotics (ampicillin, ciprofloxacin, flucloxacillin, gentamicin, erythromycin, and aztreonam) of different groups, to which all isolates were resistant. Additionally, the 23 Salmonella Typhimurium isolates showed different abilities to form the biofilm, as $10(43.47 \%)$ isolates were strong in their production, seven $(30.4 \%)$ were of moderate capacity, and the remaining six $(26 \%)$ isolates showed a weak ability to form it.

\subsection{Most Potent Lytic Phages Isolation and Characterization}

Using Salmonella Typhimurium (code; ST-4) as a host, seven phages were isolated from sewage water samples. Although the seven isolated phages can lyse their host with different sizes and shapes of the plaques, only three (42.8\%) phages showed clear lytic plaques. The three phages with clear plaques were named vB_STS-1, vB_STM-2, and vB_STS-3, and they were the only ones that were purified and propagated (titers ranged from $10^{7}$ to $10^{11} \mathrm{PFU} / \mathrm{mL}$ ). Isolate $v B$ _STM-2 was chosen as the most potent lytic phage, based on the clarity of the plaques. The plaques of the vB_STM-2 phage appeared clear, large in size (approximately $\simeq 4.5 \mathrm{~mm}$ ), and semi-regular circular in shape (Figure 1A). Morphotype characters of the three phages were examined, and the TEM images showed that both vB_STS-1 (Figure 1B) and vB_STS-3 (Figure 1D) were members of the Siphoviridae family. Siphoviruses had an icosahedral head that measures approximately $61.32 \mathrm{~nm}$ for vB_STS-1 and $47.62 \mathrm{~nm}$ in diameter. Both phages contained a long, non-contractile tail with a length of $167.21 \mathrm{~nm}$ for vB_STS-1 and $279.36 \mathrm{~nm}$ for vB_STS-3. On the other hand, the vB_STM-2 phage was classified as a myovirus, where it belongs to the Myoviridae family, per the criteria established by the International Committee on Taxonomy of Viruses. The TEM image of the vB_STM-2 phage (Figure 1C) showed that the phage contained a round head in shape with isometric symmetry ( $51.27 \mathrm{~nm}$ in diameter) and a contractile sheathed tail (94.42 $\mathrm{nm}$ in length).

\subsection{Selection of a Broad Host Spectrum and Polyvalent Phages}

The host range of three lytic phages (vB_STS-1, vB_STM-2, and vB_STS-3) was determined by spot test and EOP to confirm their host range (Table 2). However, the vB_STS-1 and vB_STS-3 phages could lyse most of the Salmonella Typhimurium isolates, and they could not infect any other bacterial strains. The results indicated that vB_STS-1 lysed $65 \%(15 / 23)$ of Salmonella isolates. However, it did not show high EOP except in 5 out of 15 positive spot-tests. The vB_STS-3 phage showed a positive spot test with only $52 \%$ $(12 / 23)$ of Salmonella, with high EOP in two isolates. Phage vB_STM-2 showed important results, in which all Salmonella Typhimurium isolates were lysed, with high EOP in 17 out of 23 Salmonella isolates, plus three non-Salmonella strains. Interestingly, the vB_STM-2 phage showed a polyvalent behavior, as it could infect non-Salmonella strains, including P. aeruginosa, S. aureus, and E. coli, while K. pneumoniae was unable to be infected. Due to the strong lytic ability of the vB_STM-2 phage, polyvalent behavior was chosen to complete the study and the Salmonella challenge experiments. 

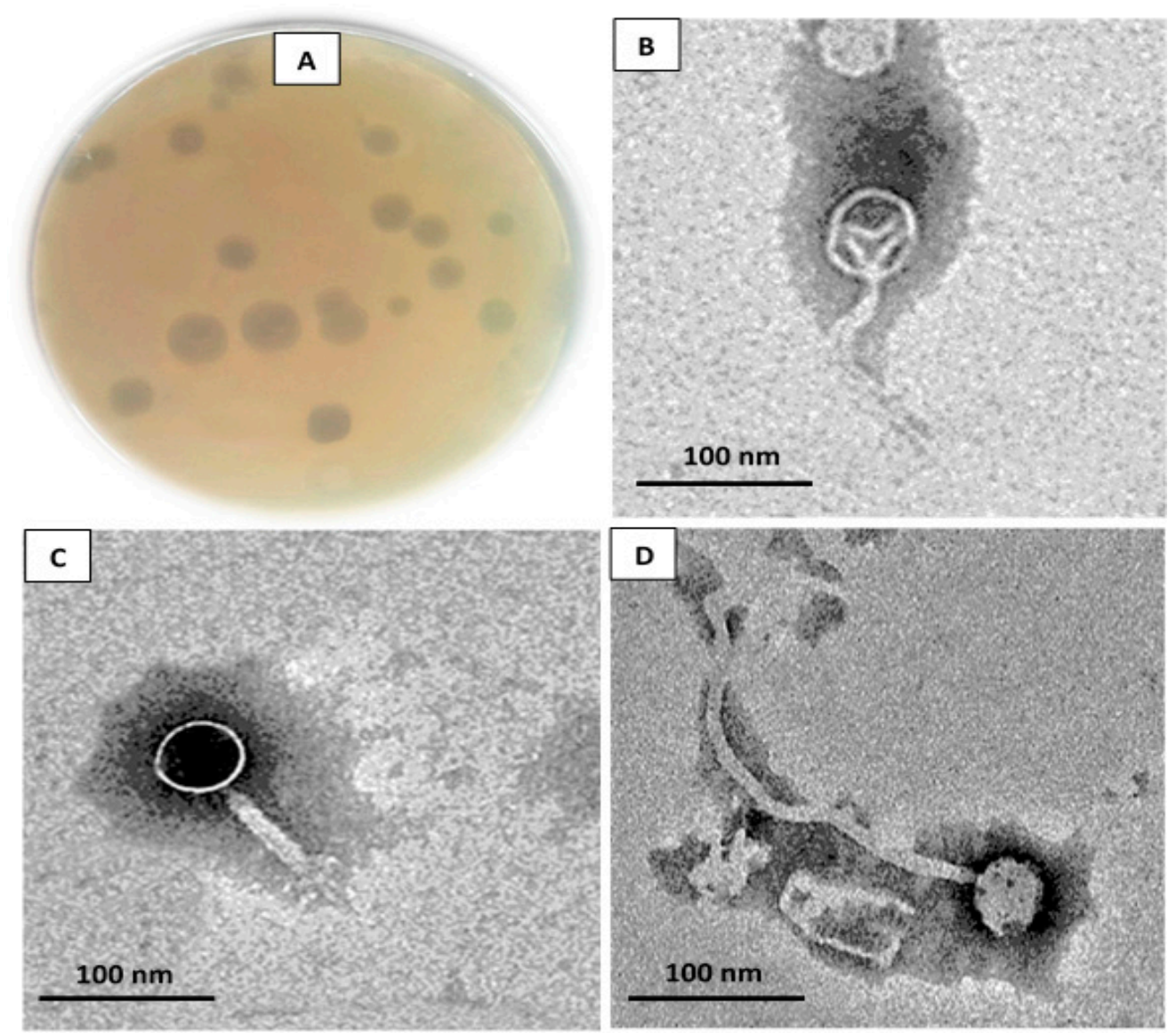

Figure 1. Salmonella Typhimurium phage characterization. (A) Clear, large circular plaques ( $\simeq 4.5 \mathrm{~mm}$ in diameter) were produced on the double-layered agar plate. Electron micrographs at 80,000 $\times$ of (B) vB_STS-1 phage (Siphovirus), (C) vB_STM-2 phage (Myovirus) and (D) vB_STS-3 phage (Siphovirus).

\subsection{Thermo and $p H$ Stability of the $v B \_S T M-2$ Phage}

The thermal and $\mathrm{pH}$ stability of the $\mathrm{vB} \_$STM-2 phage was determined to identify the extent of the phage's resistance to different temperatures (Figure 2A) and $\mathrm{pH}$ (Figure 2B).

Thermal stability: the $\mathrm{vB}$ _STM-2 phage showed resistance at measured temperatures from -20 to $55^{\circ} \mathrm{C}$ up to $24 \mathrm{~h}$. The original activity of the phage was also not adversely affected at $65^{\circ} \mathrm{C}$, where insignificant $(p<0.05)$ titer reduction was observed at $1.89 \pm 0.21$ and $2.78 \pm 0.33 \log _{10} \mathrm{PFU} / \mathrm{mL}$ after 12 and $24 \mathrm{~h}$, respectively. In contrast, a temperature of $65^{\circ} \mathrm{C}$ negatively affected the phage significantly $(p<0.05)$ when incubated for 7 days, and the titer reduction was $4.59 \pm 0.36 \log _{10} \mathrm{PFU} / \mathrm{mL}$. Furthermore, a negative effect on the phage titers was observed at $75^{\circ} \mathrm{C}$ after 7 days of incubation, whereas $6.01 \pm 0.43 \log _{10} \mathrm{PFU} / \mathrm{mL}$ was reduced from the initial phage titers $\left(7 \log _{10} \mathrm{PFU} / \mathrm{mL}\right)$.

pH stability: Similarly, the vB_STM-2 phage seemed extremely stable at different $\mathrm{pH}$ levels from 4 to 11 after incubation times from 1 to $12 \mathrm{hrs}$. At other time points, the experiment showed that the $\mathrm{vB}$-STM-2 phage was more sensitive to the alkaline than the acidic medium. At an acidic $\mathrm{pH}$ of 4 the phage titers were insignificantly $(p<0.05)$ reduced by $0.26 \pm 0.1$ and $0.34 \pm 0.03 \log _{10} \mathrm{PFU} / \mathrm{mL}$ after $24 \mathrm{~h}$ and 7 days. At a $\mathrm{pH}$ of 11 , the phage lost $3.13 \pm 0.41 \log _{10} \mathrm{PFU} / \mathrm{mL}$ of infective ability after $24 \mathrm{~h}$, while the titers were collapsed by $6.18 \pm 0.47 \log _{10} \mathrm{PFU} / \mathrm{mL}$ after 7 days.

\subsection{Biofilm Removal Effect of the vB_STM-2 Phage}

The effectiveness of the vB_STM-2 phage against the strongest biofilm-producing Salmonella Typhimurium (ST-4, ST-19, ST-30, ST-37, ST-45, and ST-49), as listed in Table 1, 
was quantitively determined (Figure 3G). Salmonella Typhimurium ST-4 (host strain) biofilm $\left(0.979 \mathrm{OD}_{570} \mathrm{~nm}\right)$ was removed by $81.2 \%, 70.5 \%, 61 \%$ and $34.7 \%$, respectively, at $10^{6}, 10^{5}, 10^{4}, 10^{3}$ and $10^{2} \mathrm{PFU} / \mathrm{mL}$ of phage titers, with no effect on cell growth $\left(1.847 \mathrm{OD}_{620} \mathrm{~nm}\right),($ Figure $3 \mathrm{~A})$. Treatment of Salmonella Typhimurium ST-19 resulted in a reduction in biofilm $\left(1.081 \mathrm{OD}_{570} \mathrm{~nm}\right)$ by $76.4 \%, 60.3 \%$, and $10 \%$ with respective titers of $10^{6}, 10^{5}$, and $10^{4} \mathrm{PFU} / \mathrm{mL}$, while the cell growth remained stable $\left(1.977 \mathrm{OD}_{620} \mathrm{~nm}\right)$ (Figure 3B). The antibiofilm effect of the vB_STM-2 phage on both Salmonella Typhimurium ST-30 and Salmonella Typhimurium ST-37 was closely related, whereas at titers of $10^{6}, 10^{5}$, and $10^{4} \mathrm{PFU} / \mathrm{mL}$, the biofilm was disrupted by $43.6 \%, 21.2 \%$, and $10.1 \%$, respectively, for Salmonella Typhimurium ST-30 $\left(0.904 \mathrm{OD}_{570} \mathrm{~nm}\right)$ and by $41 \%, 15.7 \%$, and $9.6 \%$, respectively, for Salmonella Typhimurium ST-37 $\left(1.105 \mathrm{OD}_{570} \mathrm{~nm}\right)$, (Figure 3C,D). For each previous bacterium, no effect on cell growth was observed at the previously used phage titer concentration. Phage vB_STM-2 exhibited moderate to weak strength in the biofilm $\left(0.817 \mathrm{OD}_{570} \mathrm{~nm}\right)$ removal of Salmonella Typhimurium ST-45. The maximum effect reached only $39.8 \%$ at a $10^{6} \mathrm{PFU} / \mathrm{mL}$ concentration, while it decreased to $28.2 \%$ and $15.4 \%$ at $10^{5}$ and $10^{4} \mathrm{PFU} / \mathrm{mL}$, respectively (Figure 3E). Phage vB_STM-2 showed its strongest biofilm removal activity when applied with Salmonella Typhimurium ST-49, and the cell growth $\left(1.811 \mathrm{OD}_{620} \mathrm{~nm}\right)$ remained the same. The biofilm $\left(0.927 \mathrm{OD}_{570} \mathrm{~nm}\right)$ of this bacterium was disrupted by $93.4 \%, 81 \%, 73.6 \%$ and $59.4 \%$ at $10^{6}, 10^{5}$ and $10^{4} \mathrm{PFU} / \mathrm{mL}$ of phage titers, respectively (Figure $3 \mathrm{~F}$ ).

Table 2. Spot test and EOP by the vB_STS-1, vB_STM-2, and vB_STS-3 phages against 23 Salmonella Typhimurium serovars and other bacterial strains.

\begin{tabular}{|c|c|c|c|c|c|c|c|c|c|c|c|c|c|}
\hline \multirow{3}{*}{ Bacteria } & \multicolumn{6}{|c|}{ Phages } & \multirow{3}{*}{ Bacteria } & \multicolumn{6}{|c|}{ Phages } \\
\hline & \multicolumn{2}{|c|}{ vB_STS-1 } & \multicolumn{2}{|c|}{ vB_STM-2 } & \multicolumn{2}{|c|}{ vB_STS-3 } & & \multicolumn{2}{|c|}{ vB_STS-1 } & \multicolumn{2}{|c|}{ vB_STM-2 } & \multicolumn{2}{|c|}{ vB_STS-3 } \\
\hline & ST & EOP & ST & EOP & ST & EOP & & ST & EOP & ST & EOP & ST & EOP \\
\hline $\begin{array}{l}\text { Salmonella } \\
\text { Typhimurium } \\
\text { (ST-4) Host }\end{array}$ & + & $\mathbf{M}$ & + & $\mathbf{H}$ & + & $\mathbf{H}$ & $\begin{array}{c}\text { Salmonella } \\
\text { Typhimurium } \\
\text { ST-47 }\end{array}$ & + & $\mathbf{L}$ & + & $\mathbf{H}$ & + & $\mathbf{L}$ \\
\hline $\begin{array}{c}\text { Salmonella } \\
\text { Typhimurium } \\
\text { (ST-7) }\end{array}$ & + & $\mathbf{H}$ & + & $\mathbf{H}$ & + & $\mathbf{M}$ & $\begin{array}{c}\text { Salmonella } \\
\text { Typhimurium } \\
\text { ST-49 }\end{array}$ & - & $\mathbf{N}$ & + & $\mathbf{M}$ & - & $\mathbf{N}$ \\
\hline $\begin{array}{c}\text { Salmonella } \\
\text { Typhimurium } \\
\text { (ST-9) }\end{array}$ & - & $\mathbf{N}$ & + & $\mathbf{M}$ & - & $\mathbf{N}$ & $\begin{array}{c}\text { Salmonella } \\
\text { Typhimurium } \\
\text { (ST-53) }\end{array}$ & + & $\mathbf{H}$ & + & $\mathbf{H}$ & + & $\mathbf{M}$ \\
\hline $\begin{array}{c}\text { Salmonella } \\
\text { Typhimurium } \\
\text { (ST-14) }\end{array}$ & - & $\mathbf{N}$ & + & $\mathbf{H}$ & - & $\mathbf{N}$ & $\begin{array}{c}\text { Salmonella } \\
\text { Typhimurium } \\
\text { (ST-55) }\end{array}$ & - & $\mathbf{N}$ & + & $\mathbf{M}$ & - & $\mathbf{N}$ \\
\hline $\begin{array}{c}\text { Salmonella } \\
\text { Typhimurium } \\
\text { (ST-16) }\end{array}$ & + & $\mathbf{H}$ & + & $\mathbf{H}$ & + & $\mathbf{M}$ & $\begin{array}{c}\text { Salmonella } \\
\text { Typhimurium } \\
\text { (ST-56) }\end{array}$ & + & $\mathbf{H}$ & + & $\mathbf{H}$ & + & $\mathbf{M}$ \\
\hline $\begin{array}{c}\text { Salmonella } \\
\text { Typhimurium } \\
\text { (ST-19) }\end{array}$ & + & $\mathbf{M}$ & + & $\mathbf{H}$ & + & $\mathbf{M}$ & $\begin{array}{l}\text { P. aeruginosa } \\
\text { (PsaCI-1) }\end{array}$ & - & $\mathbf{N}$ & + & $\mathbf{M}$ & - & $\mathbf{N}$ \\
\hline $\begin{array}{c}\text { Salmonella } \\
\text { Typhimurium } \\
\text { (ST-21) }\end{array}$ & - & $\mathbf{N}$ & + & $\mathbf{M}$ & + & $\mathbf{M}$ & $\begin{array}{l}\text { P. aeruginosa } \\
\text { (PsaCI-2) }\end{array}$ & - & $\mathbf{N}$ & + & $\mathbf{M}$ & - & $\mathbf{N}$ \\
\hline $\begin{array}{c}\text { Salmonella } \\
\text { Typhimurium } \\
\text { (ST-22) }\end{array}$ & - & $\mathbf{N}$ & + & $\mathbf{H}$ & - & $\mathbf{N}$ & $\begin{array}{l}\text { P. aeruginosa } \\
\text { (PsaFI-1) }\end{array}$ & - & $\mathbf{N}$ & + & $\mathbf{H}$ & - & $\mathbf{N}$ \\
\hline $\begin{array}{c}\text { Salmonella } \\
\text { Typhimurium } \\
\text { (ST-27) }\end{array}$ & + & $\mathbf{M}$ & + & $\mathbf{H}$ & + & $\mathbf{M}$ & $\begin{array}{l}\text { P. aeruginosa } \\
\text { (PsaFI-2) }\end{array}$ & - & $\mathbf{N}$ & + & $\mathbf{H}$ & - & $\mathbf{N}$ \\
\hline
\end{tabular}


Table 2. Cont.

\begin{tabular}{|c|c|c|c|c|c|c|c|c|c|c|c|c|c|}
\hline \multirow{3}{*}{ Bacteria } & \multicolumn{6}{|c|}{ Phages } & \multirow{3}{*}{ Bacteria } & \multicolumn{6}{|c|}{ Phages } \\
\hline & \multicolumn{2}{|c|}{ vB_STS-1 } & \multicolumn{2}{|c|}{ vB_STM-2 } & \multicolumn{2}{|c|}{ vB_STS-3 } & & \multicolumn{2}{|c|}{ vB_STS-1 } & \multicolumn{2}{|c|}{ vB_STM-2 } & \multicolumn{2}{|c|}{ vB_STS-3 } \\
\hline & ST & EOP & ST & EOP & ST & EOP & & ST & EOP & ST & EOP & ST & EOP \\
\hline $\begin{array}{c}\text { Salmonella } \\
\text { Typhimurium } \\
\text { (ST-30) }\end{array}$ & + & $\mathbf{H}$ & + & $\mathbf{H}$ & - & $\mathbf{N}$ & $\begin{array}{l}\text { P. aeruginosa } \\
\text { (PsaFI-1) }\end{array}$ & - & $\mathbf{N}$ & + & $\mathbf{H}$ & - & $\mathbf{N}$ \\
\hline $\begin{array}{c}\text { Salmonella } \\
\text { Typhimurium } \\
\text { (ST-33) }\end{array}$ & - & $\mathbf{N}$ & + & $\mathbf{M}$ & - & $\mathbf{N}$ & $\begin{array}{l}\text { S. aureus } \\
(\text { SaFI- } 1)\end{array}$ & - & $\mathbf{N}$ & + & $\mathbf{L}$ & - & $\mathbf{N}$ \\
\hline $\begin{array}{c}\text { Salmonella } \\
\text { Typhimurium } \\
\text { (ST-35) }\end{array}$ & + & $\mathbf{H}$ & + & $\mathbf{H}$ & + & $\mathbf{H}$ & $\begin{array}{l}\text { S. aureus } \\
(\text { SaFI- } 2)\end{array}$ & - & $\mathbf{N}$ & + & $\mathbf{M}$ & - & $\mathbf{N}$ \\
\hline $\begin{array}{c}\text { Salmonella } \\
\text { Typhimurium } \\
\text { (ST-36) }\end{array}$ & - & $\mathbf{N}$ & + & $\mathbf{M}$ & - & $\mathbf{N}$ & $\begin{array}{l}\text { S. aureus } \\
(\text { SaFI-3) }\end{array}$ & - & $\mathbf{N}$ & + & $\mathbf{L}$ & - & $\mathbf{N}$ \\
\hline $\begin{array}{c}\text { Salmonella } \\
\text { Typhimurium } \\
\text { (ST-37) }\end{array}$ & + & $\mathbf{M}$ & + & $\mathbf{H}$ & - & $\mathbf{N}$ & $\begin{array}{c}\text { E. coli } \\
(\text { EcCI-1) }\end{array}$ & - & $\mathbf{N}$ & + & $\mathbf{M}$ & - & $\mathbf{N}$ \\
\hline $\begin{array}{c}\text { Salmonella } \\
\text { Typhimurium } \\
\text { (ST-38) }\end{array}$ & + & $\mathbf{M}$ & + & $\mathbf{H}$ & + & $\mathbf{M}$ & $\begin{array}{c}\text { E. coli } \\
\text { (EcCI-2) }\end{array}$ & - & $\mathbf{N}$ & + & $\mathbf{M}$ & - & $\mathbf{N}$ \\
\hline $\begin{array}{c}\text { Salmonella } \\
\text { Typhimurium } \\
\text { (ST-41) }\end{array}$ & + & L & + & $\mathbf{H}$ & - & $\mathbf{N}$ & $\begin{array}{c}\text { E. coli } \\
\text { (EcCI-3) }\end{array}$ & - & $\mathbf{N}$ & + & $\mathbf{M}$ & - & $\mathbf{N}$ \\
\hline $\begin{array}{c}\text { Salmonella } \\
\text { Typhimurium } \\
\text { (ST-43) }\end{array}$ & + & $\mathbf{L}$ & + & $\mathbf{H}$ & - & $\mathbf{N}$ & $\begin{array}{c}\text { E. coli } \\
\text { (EcCI-4) }\end{array}$ & - & $\mathbf{N}$ & + & $\mathbf{M}$ & - & $\mathbf{N}$ \\
\hline $\begin{array}{c}\text { Salmonella } \\
\text { Typhimurium } \\
\text { (ST-45) }\end{array}$ & + & $\mathbf{M}$ & + & $\mathbf{H}$ & + & $\mathbf{L}$ & $\begin{array}{l}\text { K. pneumoniae } \\
(\mathrm{KpCI}-1)\end{array}$ & - & $\mathbf{N}$ & - & $\mathbf{N}$ & - & $\mathbf{N}$ \\
\hline
\end{tabular}

The brackets inside the bacterial column in the table indicate the isolate ID, ST: spot-assay technique, +: positive reaction (the isolate caused lysis by the phage), -: negative reaction (the isolate does not cause lysis by the phage), EOP; efficiency of plating, $\mathrm{H}$ : high efficiency of plating $(0.5-1.0)$, M: moderate efficiency of plating $(0.2-0.4)$, L: low efficiency of plating $(0.001-0.1)$, N: no efficiency of plating (inefficient) $(p<0.05)$.

A

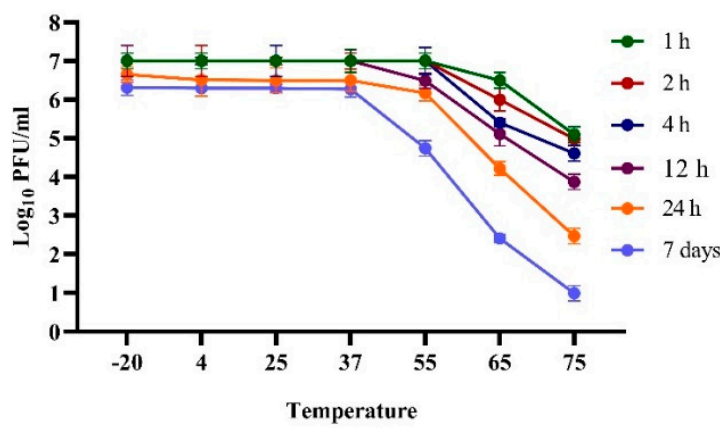

B

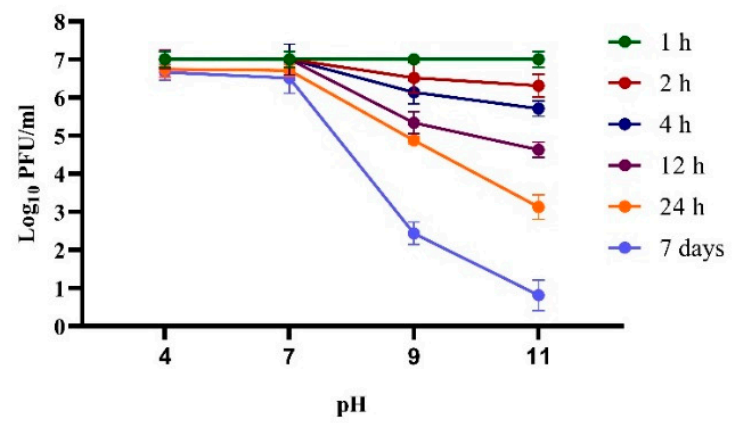

Figure 2. Virion stability of the $\mathrm{vB}_{-}$STM-2 phage at different times $(1,2,4,12,24 \mathrm{~h}$ and 7 days) (A) Thermal tolerance at $\left(-20,4,25,37,55,65\right.$ and $75{ }^{\circ} \mathrm{C}$, and (B) pH values of 4, 7, 9 and 11. The two experiments were performed in triplicate with standard deviation $( \pm \mathrm{SD})$. One-way ANOVA was used to achieve quantitative analyses with the least significant difference (LSD) test variance analysis at $p<0.05$. 


\subsection{The Ability of the vB_STM-2 Phage as a Natural Antibacterial \\ Lytic Potency in TSB Medium (Culture Clearance)}

The results illustrated in Figure 4A clearly show the efficiency of the vB_STM-2 phage in controlling Salmonella in a liquid medium. The optical density $\left(\mathrm{OD}_{620} \mathrm{~nm}\right)$ of Salmonella Typhimurium culture ST-4 showed $1.65 \pm 0.31 \mathrm{OD}_{570} \mathrm{~nm}$ at the end of the experiment. On the other hand, the phage-treated culture flask showed no absorbance at any measurement times, except at the first hour $\left(0.10 \pm 0.01 \mathrm{O}_{\mathrm{D} 570} \mathrm{~nm}\right)$ of incubation. In addition, the results obtained from counting the plates confirm the lytic ability of the vB_STM-2 phage. At $3 \mathrm{~h}$ of incubation, the colony count was $0.19 \pm 0.03 \log _{10} \mathrm{CFU} / \mathrm{mL}$, while no colonies were detected at other times of the experiment (B).

\subsection{Control of Salmonella in Food and Phage Stability}

In short (7 days) and long (27 days) term assays, both the efficiency and stability of the vB_STM-2 phage were measured in food (chicken breast squares $2 \times 2 \mathrm{~cm}$ ).

Short-term assay: the recoverable $\log _{10}$ of Salmonella Typhimurium (ST-4) in nontreated phage sections was significantly $(p<0.05)$ increased by increasing the time. Therefore, the titer was $0.81 \pm 0.11 \log _{10} \mathrm{CFU} / \mathrm{cm}^{2}$ on day one, $3.27 \pm 0.24 \log _{10} \mathrm{CFU} / \mathrm{cm}^{2}$ on day two, $4.55 \pm 0.37 \log _{10} \mathrm{CFU} / \mathrm{cm}^{2}$ on day four, and $7.00 \pm 0.63$ on the last day. Otherwise, the recoverable $\log _{10}$ of Salmonella Typhimurium (ST-4) from phage-treated chicken breast cuts was significantly $(p<0.05)$ decreased, and it was only $0.88 \pm 0.17 \log _{10} \mathrm{CFU} / \mathrm{cm}^{2}$ on day 7 . In other words, the vB_STM-2 phage reduced Salmonella by $6.12 \pm 43 \log _{10} \mathrm{CFU} / \mathrm{cm}^{2}$ on day 7. Nevertheless, the phage showed high stability throughout the experiment times with a recovery titer of $6.87 \pm 43 \log _{10} \mathrm{PFU} / \mathrm{cm}^{2}$ on day 7 , losing only $1.13 \pm 0.16 \log _{10} \mathrm{PFU} / \mathrm{cm}^{2}$ from the initial titer (Figure 5A).

Long-term assay: In this experiment, the duration was increased to 27 days in order to ensure the effectiveness and stability of the vB_STM-2 phage. On days 2 and 27 , the $\log _{10}$ recovery of Salmonella from the non-treated chicken breast section was $0.92 \pm 0.08 \log _{10} \mathrm{CFU} / \mathrm{cm}^{2}$ and $5.13 \pm 0.44 \log _{10} \mathrm{CFU} / \mathrm{cm}^{2}$, respectively. In contrast, there was a highly significant decrease $(p<0.05)$ in the count of Salmonella recovered from chicken breast cuts treated with phage. At the same two previous times, only $0.11 \pm 0.02 \log _{10} \mathrm{CFU} / \mathrm{cm}^{2}$ was recovered on day 2 , while $1.10 \pm 0.12 \log _{10} \mathrm{CFU} / \mathrm{cm}^{2}$ was recovered on day 27. It is worth noting that the $\mathrm{vB}$ _STM-2 phage showed a high stability strength, whereas there was a slight shortage of titers at all times, even on the last day. Accordingly, on day 27, the recovered phage titers were $5.88 \pm 0.41 \log _{10} \mathrm{PFU} / \mathrm{cm}^{2}$, and only $2.12 \pm 0.22 \log _{10} \mathrm{PFU} / \mathrm{cm}^{2}$ (insignificant) of the original titers were lost (Figure $5 \mathrm{~B}$ ). 

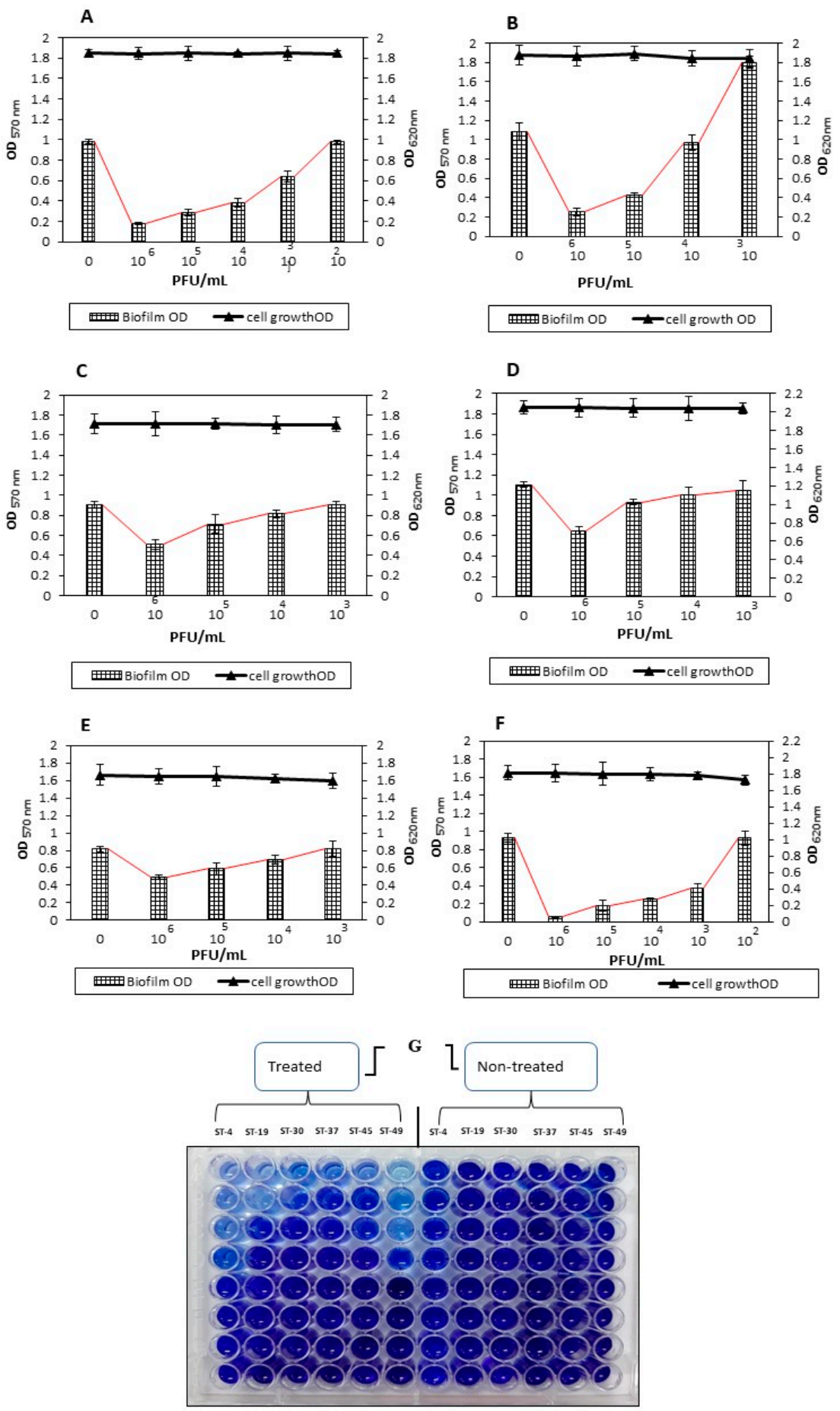

Figure 3. The qualitative anti-biofilm capacity of the vB_STM-2 phage in 96-well microplate against biofilms of Salmonella Typhimurium isolates (A) ST-4, (B) ST-19, (C) ST-30, (D) ST-37, (E) ST-45, (F) ST-49 and (G) 96-wells of tissue culture plates. The vertical wells of the plate on the left are the antibiofilm (phage-treated) wells, while those on the right re the biofilm controls (without adding phage) for these bacteria. One-way ANOVA was used to achieve quantitative analyses with the least significant difference (LSD) test variance analysis at $p<0.05$. 

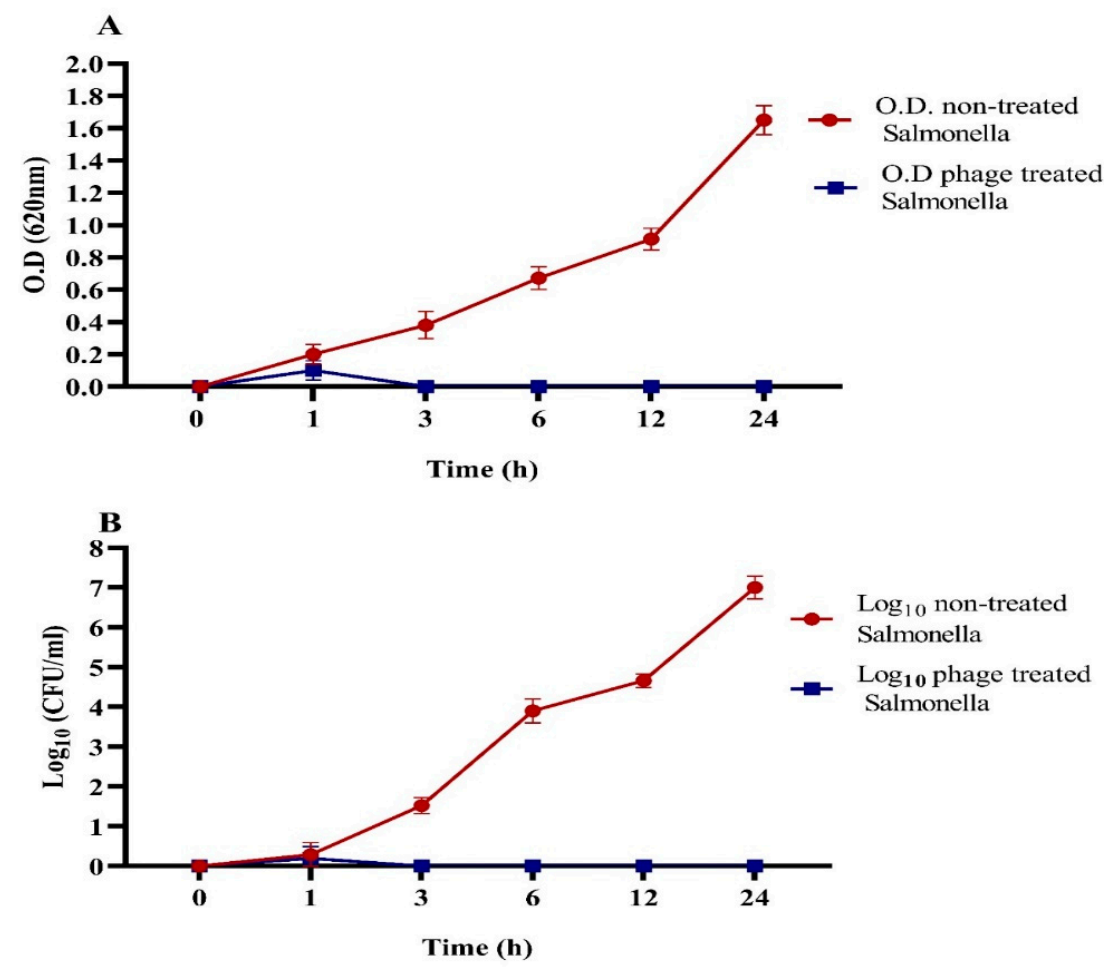

Figure 4. The lytic ability of the vB_STM-2 phage in the challenge of Salmonella Typhimurium ST-4 serovar in (A) TSB medium (absorbance of $\mathrm{OD}_{620} \mathrm{~nm}$ ) and (B) TSA medium (colonies count CFU/mL). Experiments were performed in triplicate at each time point with a standard deviation $( \pm S D)$. Oneway ANOVA was used to achieve quantitative analyses with the least significant difference (LSD) test variance analysis at $p<0.05$.

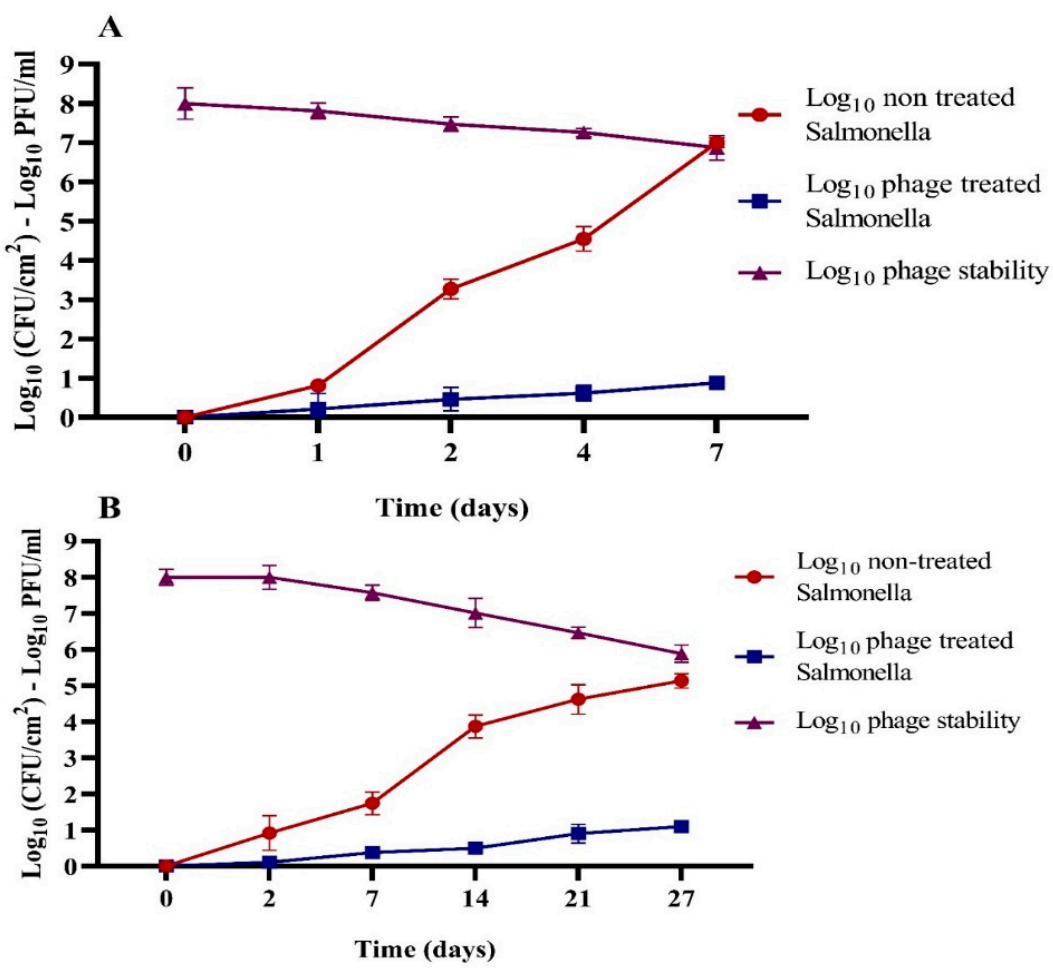

Figure 5. Efficacy and virion stability of the vB_STM-2 phage in eliminating Salmonella Typhimurium ST-4 serovar after (A) 7 days at $4{ }^{\circ} \mathrm{C}$, and (B) long-term assay (27 days) at $-20^{\circ} \mathrm{C}$. One-way ANOVA was used to achieve quantitative analyses with the least significant difference (LSD) test variance analysis at $p<0.05$. 


\section{Discussion}

The emergency of multiple-drug resistant (MDR) bacteria in food has become a major and complex problem for both producers and consumers, posing a serious threat to human public health $[17,61,62]$. For example, Salmonella Typhimurium has become the most frequent serovar primarily responsible for salmonellosis in humans worldwide $[7,8]$. Antibiotics are a well-known strategy to control Salmonella [1], but it has acquired resistance to these antimicrobials [17], making it more difficult to resist disease outbreaks [63].

Therefore, this study aimed to search for a safe and effective alternative to control multidrug-resistant Salmonella Typhimurium and its biofilm by broad-spectrum phage isolation with the string lytic effect.

In this study, Salmonella Typhimurium serovars previously isolated from food sources were confirmed biochemically, serologically, and using the Biomerieux VITEK 2 system. Additionally, all Salmonella Typhimurium serovars used were multi-drug resistant, and nearly half showed strong biofilm production behavior. Many previous studies are in line with our results, where it was found that Salmonella Typhimurium, S. enterica, and S. enteritidis serovars are the most prevalent for the occurrence of salmonellosis outbreaks worldwide $[8,64]$. Many other studies have also confirmed that the effect of the frontline antibiotics used to arrest Salmonella have become weak or negligible due to bacteria gaining resistance [65-67]. In accordance with previous results, antibiotic-resistant genes were common in Salmonella Typhimurium [68]. The European Food Safety Authority (EFSA) announcement that $64.2 \%$ of 123 Salmonella Typhimurium strains obtained from pig carcasses were resistant to many antibiotics is concerning [69]. It is worth noting that bacteria may acquire this resistance due to incorrect use, including a lack of need for antibiotics in many cases [70-72]. The mechanism by which bacteria can resist the action of antibiotics may be the over-expression of efflux pumps that lead to the active efflux of antibiotics from the bacterial cell and restrict the antibiotics to their target sites by decreasing the selective permeability of the bacterial cell wall. In addition, bacteria may produce target enzymes to circumvent the drug's antibacterial activity [73-75]. Salmonella Typhimurium (ST-4) was used to isolate phage, as it is the strongest isolate for biofilm production. More than one study states that biofilm is a rising challenge as it gives the pathogen more resistance to antibiotics. Hence, it is difficult to eradicate [76-78]. Out of the seven isolated phages, only three $(42.8 \%)$ phages showed clear lytic plaques, which were named vB_STS-1, vB_STM-2, and vB_STS-3. Among the three isolates, vB_STM-2 belonging to the Myoviridae family was chosen to achieve the desired goal of this study (most potent lytic phage). The results of the lytic activity indicated that $100 \%$ of Salmonella Typhimurium isolates and non-Salmonella strains were lysed, including P. aeruginosa, S. aureus, and E. coli. These results align with previous findings in which phages have been developed to deal with MDR Salmonella Typhimurium [32,79]. These findings are in accordance with previous works by Park et al. [26]. Parra and Robeson [27] reported that some polyvalent phages were observed, especially among the phages of the Enterobacteriaceae family. In addition, the study by Malki et al. [28] showed that phages with polyvalent behavior could infect strains from either different genera or species, which is preferable to others. In addition to controlling bacterial resistance by phages, there is recent literature to overcome the problem of bacterial resistance using metal-based antibacterial compounds instead of conventional antibiotics [80].

The previous literature indicated that the Myoviridae family's phages could potentially control Salmonella $[81,82]$.

Here, vB_STM-2 showed a broad host range of other phages, which is an important charitarian of the use of phages in the treatment of infection, as reported by previous studies $[83,84]$. In addition, the phage's polyvalent behavior makes it a preferred choice for use in biocontrol applications [85-87].

The differences between phages in their host range may be due to restriction endonucleases changes, non-specific binding receptors [88,89], and the formation of resis- 
tance to phage through a variety of mechanisms, known as insensitive bacterial mutants (BIM) $[90,91]$.

In the phage thermal and pH stability study, the vB_STM-2 phage showed durability over a wide range of temperatures and at different $\mathrm{pH}$ levels. Consistent with previous studies, phages are stable at various temperatures, pHs, and biotic conditions [92,93]. Additionally, our findings are in agreement with those of Jamalludeen et al. [53]. They decided that most of the phages could resist different $\mathrm{pH}$ levels (5-9) without affecting their stability or structure. However, extreme degrees may lead to thickening, deposition, or aggregation of the phages [94].

Our data imply that the vB_STM-2 phage can diminish or eradicate the tested Salmonella Typhimurium (ST-4, ST-19, ST-30, ST-37, ST-45, and ST-49) biofilms. In a previous work [82] on Salmonella Typhimurium biofilm, the phage used was able to reduce the biofilm by 44-63\%. Here, the removal rate reached 93.4\% (e.g., Salmonella Typhimurium ST-49). Concurrent studies confirm the ability of phages to eradicate biofilms in vitro assays $[82,95,96]$. In a previous study, the biofilms of multi-drug resistant bacteria were overcome by natural antimicrobial agents $[86,97]$. In an attempt to find an explanation for how the phage attacks the biofilm, it may be due to the phage's ability to infect cells embedded in biofilm throughout their environment [89]. In addition, the high number of cells within the biofilm protect the phage virions from infection [89]. The mechanism of this action is the penetration of the EPS layers of biofilms, which become less hard [98], less consistent [99,100], or no longer compact [101], and the production of EPS depolymerizes, which can break down the biofilm matrix [102,103].

Our results indicated that the vB_STM-2 phage showed efficiency in inhibiting Salmonella in a phage-treated culture flask (culture clearance). In a liquid medium, phage-treated Salmonella culture showed no absorbance after $3 \mathrm{~h}$ of incubation. Following our results, other researchers isolated phages named FGCSSa1, LPST10, LPST18, and LPST23 against Salmonella Typhimurium PT160, which could inhibit growth from growth 2 to 6 hrs [104].

The phage application results showed the efficacy and stability of the vB_STM-2 phage in the elimination of Salmonella Typhimurium (ST-4) from the chicken breast section with significant $(p<0.05)$ virion stability. In addition, the severe Salmonella count declined in both the short-term (7 days) and long-term (27 days) assays. Hence, the decrease was from $7 \pm 0.63 \log _{10} \mathrm{CFU} / \mathrm{cm}^{2}$ to $0.88 \pm 0.17 \log _{10} \mathrm{CFU} / \mathrm{cm}^{2}$ on the seventh day of the short assay, while the count was diminished significantly $(p<0.05)$ from $5.13 \pm 0.44 \log _{10} \mathrm{CFU} / \mathrm{cm}^{2}$ to $1.1 \pm 0.12 \log _{10} \mathrm{CFU} / \mathrm{cm}^{2}$ on day 27 of the long-term assay. Interestingly, phage titers remained stable in both periods, with slight insignificant $(p<0.05)$ losses. Many previous studies on Salmonella have observed that phages could reduce counts in different food matrices [59,105-107]. Consistent with our data, a recent study exhibited the stability of phages against Salmonella in chicken breast [82].

\section{Conclusions}

We can conclude from the obtained results that three phages that showed clear lytic plaques, namely, vB_STS-1, vB_STM-2, and vB_STS-3, were isolated, the most potent of which was vB_STM-2, which belongs to the Myoviridae family. This phage exhibited strong stability at different temperatures and a wide range of $\mathrm{pH}$ values. The isolated phage showed high efficacy in reducing Salmonella Typhimurium below the detectable limit throughout liquid media and chicken breast challenges. Additionally, it showed a potential effect in the elimination/reduction of its biofilm. Therefore, this phage is considered a prime candidate for combating multi-drug-resistant Salmonella Typhimurium and its biofilms.

Author Contributions: Conceptualization, A.R.S., A.A.H. and M.A.A.; data curation, I.M.A.A., A.R.S., A.A.H., E.E.R. and M.A.A.; formal analysis, I.M.A.A., A.R.S., A.A.H. and E.E.R.; investigation, I.M.A.A., A.R.S., A.A.H., E.E.R., H.E.S. and M.A.A.; methodology, I.M.A.A., A.R.S., A.A.H. and E.E.R.; project administration, A.R.S., A.A.H., H.E.S. and M.A.A.; software, I.M.A.A., A.R.S. and A.A.H.; resources, I.M.A.A., A.R.S., A.A.H., E.E.R., H.E.S. and M.A.A.; supervision, A.R.S., A.A.H., 
H.E.S. and M.A.A.; validation, I.M.A.A., A.R.S., A.A.H., E.E.R., H.E.S. and M.A.A.; visualization, I.M.A.A., A.R.S., A.A.H., E.E.R., H.E.S. and M.A.A.; writing-original draft, I.M.A.A., A.R.S. and A.A.H.; writing-review and editing, I.M.A.A., A.R.S., A.A.H., E.E.R., H.E.S. and M.A.A. All authors have read and agreed to the published version of the manuscript.

Funding: This research received no external funding.

Institutional Review Board Statement: Not applicable.

Informed Consent Statement: Not applicable.

Data Availability Statement: Not applicable.

Conflicts of Interest: The authors declare no conflict of interest.

\section{References}

1. Musyoka, J.N.; Abong', G.O.; Mbogo, D.M.; Fuchs, R.; Low, J.; Heck, S.; Muzhingi, T. Effects of Acidification and Preservatives on Microbial Growth during Storage of Orange Fleshed Sweet Potato Puree. Int. J. Food Sci. 2018, 2018, 8410747. [CrossRef] [PubMed]

2. Lamas, A.; Regal, P.; Vazquez, B.; Miranda, J.; Cepeda, A.; Franco, C.M. Salmonella and Campylobacter biofilm formation: A comparative assessment from farm to fork. J. Sci. Food Agric. 2018, 98, 4014-4032. [CrossRef]

3. Abu-Shahba, M.S.; Mansour, M.M.; Mohamed, H.I.; Sofy, M.R. Comparative Cultivation and Biochemical Analysis of Iceberg Lettuce Grown in Sand Soil and Hydroponics with or without Microbubbles and Macrobubbles. J. Soil Sci. Plant Nutr. 2021, 21, 389-403. [CrossRef]

4. Galletti, J.; Tobaldini-Valerio, F.K.; Silva, S.; Kioshima, É.S.; Pereira, L.T.; Bruschi, M.; Negri, M.; Svidzinski, T.I.E. Antibiofilm activity of propolis extract on Fusarium species from onychomycosis. Futur. Microbiol. 2017, 12, 1311-1321. [CrossRef] [PubMed]

5. Pobiega, K.; Przybył, J.L.; Żubernik, J.; Gniewosz, M. Prolonging the Shelf Life of Cherry Tomatoes by Pullulan Coating with Ethanol Extract of Propolis During Refrigerated Storage. Food Bioprocess Technol. 2020, 13, 1447-1461. [CrossRef]

6. CDC. Salmonella Homepage. 2016. Available online: https://www.cdc.gov/salmonella/index.html (accessed on 15 January 2021).

7. Demirbilek, S.K. Salmonellosis in Animals. In Salmonella-A Re-Emerging Pathogen; IntechOpen Limited: London, UK, 2018.

8. Ferrari, R.; Rosario, D.K.A.; Neto, A.C.; Mano, S.B.; Figueiredo, E.E.S.; Conte-Junior, C.A. Worldwide Epidemiology of Salmonella Serovars in Animal-Based Foods: A Meta-analysis. Appl. Environ. Microbiol. 2019, 85, e00591-19. [CrossRef]

9. Mueller-Doblies, D.; Speed, K.C.R.; Kidd, S.; Davies, R.H. Salmonella Typhimurium in livestock in Great Britain-Trends observed over a 32-year period. Epidemiol. Infect. 2018, 146, 409-422. [CrossRef]

10. Majowicz, S.E.; Musto, J.; Scallan, E.; Angulo, F.J.; Kirk, M.; O’Brien, S.J.; Jones, T.F.; Fazil, A.; Hoekstra, R.M. The Global Burden of Nontyphoidal Salmonella Gastroenteritis. Clin. Infect. Dis. 2010, 50, 882-889. [CrossRef]

11. Hernandez, S.M.; Keel, K.; Sanchez, S.; Trees, E.; Gerner-Smidt, P.; Adams, J.K.; Cheng, Y.; Ray, A.; Martin, G.; Presotto, A.; et al. Epidemiology of a Salmonella enterica subsp. enterica Serovar Typhimurium Strain Associated with a Songbird Outbreak. Appl. Environ. Microbiol. 2012, 78, 7290-7298. [CrossRef] [PubMed]

12. Guo, C.; Hoekstra, R.M.; Schroeder, C.M.; Pires, S.M.; Ong, K.L.; Hartnett, E.; Naugle, A.; Harman, J.; Bennett, P.; Cieslak, P.; et al. Application of Bayesian Techniques to Model the Burden of Human Salmonellosis Attributable to U.S. Food Commodities at the Point of Processing: Adaptation of a Danish Model. Foodborne Pathog. Dis. 2011, 8, 509-516. [CrossRef]

13. Marchello, C.S.; Dale, A.P.; Pisharody, S.; Rubach, M.P.; Crump, J.A. A Systematic Review and Meta-analysis of the Prevalence of Community-Onset Bloodstream Infections among Hospitalized Patients in Africa and Asia. Antimicrob. Agents Chemother. 2019, 64, 01974-19. [CrossRef] [PubMed]

14. De Carvalho, C.C.C.R. Marine Biofilms: A Successful Microbial Strategy with Economic Implications. Front. Mar. Sci. 2018, 5, 126. [CrossRef]

15. Mah, T.-F. Biofilm-specific antibiotic resistance. Futur. Microbiol. 2012, 7, 1061-1072. [CrossRef] [PubMed]

16. Jiang, Y.; Geng, M.; Bai, L. Targeting Biofilms Therapy: Current Research Strategies and Development Hurdles. Microorganisms 2020, 8, 1222. [CrossRef]

17. Agyare, C.; Boamah, V.E.; Zumbi, C.N.; Osei, F.B. Antibiotic Use in Poultry Production and Its Effects on Bacterial Resistance. In Antimicrobial Resistance-A Global Threat; Kumar, Y., Ed.; IntechOpen: London, UK, 2018; pp. 33-51, ISBN 978-1-78985-783-2.

18. Moye, Z.D.; Woolston, J.; Sulakvelidze, A. Bacteriophage Applications for Food Production and Processing. Viruses 2018, 10, 205. [CrossRef] [PubMed]

19. LeLièvre, V.; Besnard, A.; Schlusselhuber, M.; Desmasures, N.; Dalmasso, M. Phages for biocontrol in foods: What opportunities for Salmonella sp. control along the dairy food chain? Food Microbiol. 2019, 78, 89-98. [CrossRef]

20. García-Anaya, M.C.; Sepulveda, D.R.; Sáenz-Mendoza, A.I.; Rios-Velasco, C.; Zamudio-Flores, P.B.; Acosta-Muñiz, C.H. Phages as biocontrol agents in dairy products. Trends Food Sci. Technol. 2020, 95, 10-20. [CrossRef] 
21. Tang, F.; Zhang, P.; Zhang, Q.; Xue, F.; Ren, J.; Sun, J.; Qu, Z.; Zhuge, X.; Li, D.; Wang, J.; et al. Isolation and characterization of a broad-spectrum phage of multiple drug resistant Salmonella and its therapeutic utility in mice. Microb. Pathog. 2019, 126, 193-198. [CrossRef] [PubMed]

22. Abhisingha, M.; Dumnil, J.; Pitaksutheepong, C. Efficiency of phage cocktail to reduce Salmonella Typhimurium on chicken meat during low temperature storage. LWT 2020, 129, 109580. [CrossRef]

23. Li, Z.; Ma, W.; Li, W.; Ding, Y.; Zhang, Y.; Yang, Q.; Wang, J.; Wang, X. A broad-spectrum phage controls multidrug-resistant Salmonella in liquid eggs. Food Res. Int. 2020, 132, 109011. [CrossRef]

24. Petsong, K.; Benjakul, S.; Vongkamjan, K. Evaluation of storage conditions and efficiency of a novel microencapsulated Salmonella phage cocktail for controlling S. enteritidis and S. typhimurium in-vitro and in fresh foods. Food Microbiol. 2019, 83, 167-174. [CrossRef]

25. Ackermann, H.-W.; Audurier, A.; Berthiaume, L.; Jones, L.A.; Mayo, J.A.; Vidaver, A.K. Guidelines for Bacteriophage Characterization. Adv. Appl. Microbiol. 1978, 23, 1-24. [CrossRef]

26. Park, M.; Lee, J.-H.; Shin, H.; Kim, M.; Choi, J.; Kang, D.-H.; Heu, S.; Ryu, S. Characterization and Comparative Genomic Analysis of a Novel Bacteriophage, SFP10, Simultaneously Inhibiting both Salmonella enterica and Escherichia coli O157:H. Appl. Environ. Microbiol. 2011, 78, 58-69. [CrossRef]

27. Parra, B.; Robeson, J. Selection of polyvalent bacteriophages infecting Salmonella enterica serovar Choleraesuis. Electron. J. Biotechnol. 2016, 21, 72-76. [CrossRef]

28. Malki, K.; Kula, A.; Bruder, K.; Sible, E.; Hatzopoulos, T.; Steidel, S.; Watkins, S.C.; Putonti, C. Bacteriophages isolated from Lake Michigan demonstrate broad host-range across several bacterial phyla. Virol. J. 2015, 12, 164. [CrossRef] [PubMed]

29. Hungaro, H.M.; Mendonça, R.C.S.; Gouvêa, D.M.; Vanetti, M.C.D.; de Oliveira Pinto, C.L. Use of bacteriophages to reduce Salmonella in chicken skin in comparison with chemical agents. Food Res. Int. 2013, 52, 75-81. [CrossRef]

30. Augustine, J.; Bhat, S.G. Biocontrol of salmonella enteritidis in spiked chicken cuts by lytic bacteriophages $\varphi s p-1$ and $\varphi s p-3$. J. Basic Microbiol. 2015, 55, 500-503. [CrossRef] [PubMed]

31. Bigwood, T.; Hudson, J.A.; Billington, C.; Carey-Smith, G.V.; Heinemann, J.A. Phage inactivation of foodborne pathogens on cooked and raw meat. Food Microbiol. 2008, 25, 400-406. [CrossRef]

32. Hooton, S.P.; Atterbury, R.; Connerton, I.F. Application of a bacteriophage cocktail to reduce Salmonella Typhimurium U288 contamination on pig skin. Int. J. Food Microbiol. 2011, 151, 157-163. [CrossRef]

33. Kocharunchitt, C.; Ross, T.; McNeil, D. Use of bacteriophages as biocontrol agents to control Salmonella associated with seed sprouts. Int. J. Food Microbiol. 2009, 128, 453-459. [CrossRef]

34. Modi, R.; Hirvi, Y.; Hill, A.; Griffiths, M.W. Effect of Phage on Survival of Salmonella Enteritidis during Manufacture and Storage of Cheddar Cheese Made from Raw and Pasteurized Milk. J. Food Prot. 2001, 64, 927-933. [CrossRef]

35. Silliker, J.; Taylor, W. Isolation of salmonellae from food samples: Ii. The effect of added food samples upon the performance of enrichment broths. Appl. Microbiol. 1958, 6, 228-232. [CrossRef]

36. ISO. Microbiology of food and animal feeding stuffs-horizontal method for the detection of Salmonella spp. Amendment 1: Anex d: Detection of Salmonella spp. In Animal Faeces and in Environmental Samples from the Primary Production Stage; ISO: Geneva, Switzerland, 2007.

37. Sieuwerts, S.; De Bok, F.; Mols, E.; De Vos, W.; Vlieg, J.V.H. A simple and fast method for determining colony forming units. Lett. Appl. Microbiol. 2008, 47, 275-278. [CrossRef]

38. Søgaard, M.; Nørgaard, M.; Schønheyder, H.C. First Notification of Positive Blood Cultures and the High Accuracy of the Gram Stain Report. J. Clin. Microbiol. 2007, 45, 1113-1117. [CrossRef] [PubMed]

39. Douglas, W.; Waltman, R.; Gast, K.; Mallinson, E. Salmonellosis. A Laboratory Manual for the Isolation and Identification of Avian Pathogens, 4th ed.; American Association of Avian Pathologists: Kenett Square, PA, USA, 1998.

40. Bossé, J. Manual of standards for diagnostic tests and vaccines. Can. Vet. J. 2000, 39, 183.

41. Kauffman, G. Kauffmann white scheme. J. Acta. Path. Microbiol. Sci. 1974, 61, 385.

42. Santiviago, C.; Toro, C.S.; Bucarey, S.A.; Mora, G.C. A chromosomal region surrounding the ompD porin gene marks a genetic difference between Salmonella typhi and the majority of Salmonella serovars. Microbiology 2001, 147, 1897-1907. [CrossRef] [PubMed]

43. Bauer, A. Antibiotic susceptibility testing by a standardized single disc method. Am. J. Clin. Pathol. 1966, 45, 149-158. [CrossRef]

44. NCCLS/CLSI. Performance Standards for Antimicrobial Susceptibility Testing; National Committee for Clinical Laboratory Standards/Clinical and Laboratory Standards Institute: Wayne, MI, USA, 2007.

45. Stepanović, S.; Vuković, D.; Hola, V.; DI Bonaventura, G.; Djukić, S.; Ćirković, I.; Ruzicka, F. Quantification of biofilm in microtiter plates: Overview of testing conditions and practical recommendations for assessment of biofilm production by staphylococci. APMIS 2007, 115, 891-899. [CrossRef] [PubMed]

46. Bibi, Z.; Abbas, Z.; Rehman, S.U. The phage P.E1isolated from hospital sewage reduces the growth of Escherichia coli. Biocontrol Sci. Technol. 2015, 26, 181-188. [CrossRef]

47. Capra, M.; Quiberoni, A.; Reinheimer, J. Thermal and chemical resistance of Lactobacillus casei and Lactobacillus paracasei bacteriophages. Lett. Appl. Microbiol. 2004, 38, 499-504. [CrossRef]

48. Sangha, K.K.; Kumar, B.V.S.; Agrawal, R.K.; Deka, D.; Verma, R. Proteomic Characterization of Lytic Bacteriophages of Staphylococcus aureus Isolated from Sewage Affluent of India. Int. Sch. Res. Not. 2014, 2014, 265298. [CrossRef] [PubMed] 
49. Mirzaei, M.K.; Nilsson, A.S. Correction: Isolation of Phages for Phage Therapy: A Comparison of Spot Tests and Efficiency of Plating Analyses for Determination of Host Range and Efficacy. PLoS ONE 2015, 10, e0127606. [CrossRef] [PubMed]

50. Ackermann, H.-W. Bacteriophage Electron Microscopy. Adv. Appl. Microbiol. 2012, 82, 1-32. [CrossRef]

51. Accolas, J.-P.; Spillmann, H. The Morphology of Six Bacteriophages of Streptococcus thermophilus. J. Appl. Bacteriol. 1979, 47, 135-144. [CrossRef]

52. Philipson, L.; Albertsson, P.; Frick, G. The purification and concentration of viruses by aqueous polymer phase systems. Virology 1960, 11, 553-571. [CrossRef]

53. Jamalludeen, N.; Johnson, R.P.; Friendship, R.; Kropinski, A.; Lingohr, E.J.; Gyles, C.L. Isolation and characterization of nine bacteriophages that lyse O149 enterotoxigenic Escherichia coli. Veter Microbiol. 2007, 124, 47-57. [CrossRef]

54. Bekir, K.; Ben Abdallah, F.; Ellafi, A.; Bakhrouf, A. Adherence assays and slime production of Staphylococcus aureus strains after their incubation in seawater microcosms. Ann. Microbiol. 2011, 61, 819-823. [CrossRef]

55. Else, T.A.; Pantle, C.R.; Amy, P.S. Boundaries for Biofilm Formation: Humidity and Temperature. Appl. Environ. Microbiol. 2003, 69, 5006-5010. [CrossRef]

56. Kostaki, M.; Chorianopoulos, N.; Braxou, E.; Nychas, G.-J.; Giaouris, E. Differential Biofilm Formation and Chemical Disinfection Resistance of Sessile Cells of Listeria monocytogenes Strains under Monospecies and Dual-Species (with Salmonella enterica) Conditions. Appl. Environ. Microbiol. 2012, 78, 2586-2595. [CrossRef]

57. Kusumaningrum, H.D.; Van Asselt, E.D.; Beumer, R.R.; Zwietering, M.H. A Quantitative Analysis of Cross-Contamination of Salmonella and Campylobacter spp. via Domestic Kitchen Surfaces. J. Food Prot. 2004, 67, 1892-1903. [CrossRef]

58. FDA. Bacteriological Analytical Manual; Food and Drug Administration: Arlington, VA, USA, 2002.

59. Spricigo, D.A.; Bardina, C.; Cortés, P.; Llagostera, M. Use of a bacteriophage cocktail to control Salmonella in food and the food industry. Int. J. Food Microbiol. 2013, 165, 169-174. [CrossRef]

60. Tomat, D.; Casabonne, C.; Aquili, V.; Balagué, C.; Quiberoni, A. Evaluation of a novel cocktail of six lytic bacteriophages against Shiga toxin-producing Escherichia coli in broth, milk and meat. Food Microbiol. 2018, 76, 434-442. [CrossRef]

61. Sofy, A.; Sofy, M.; Hmed, A.; Dawoud, R.; Alnaggar, A.; Soliman, A.; El-Dougdoug, N. Ameliorating the Adverse Effects of Tomato mosaic tobamovirus Infecting Tomato Plants in Egypt by Boosting Immunity in Tomato Plants Using Zinc Oxide Nanoparticles. Molecules 2021, 26, 1337. [CrossRef]

62. Sofy, A.; Sofy, M.; Hmed, A.; Dawoud, R.; Refaey, E.; Mohamed, H.; El-Dougdoug, N. Molecular Characterization of the Alfalfa mosaic virus Infecting Solanum melongena in Egypt and the Control of Its Deleterious Effects with Melatonin and Salicylic Acid. Plants 2021, 10, 459. [CrossRef]

63. Fong, K.; Mu, K.; Rheault, J.-G.; Levesque, R.C.; Kitts, D.D.; Delaquis, P.; Goodridge, L.; Wang, S. Bacteriophage-Insensitive Mutants of Antimicrobial-Resistant Salmonella enterica are Altered in their Tetracycline Resistance and Virulence in Caco-2 Intestinal Cells. Int. J. Mol. Sci. 2020, 21, 1883. [CrossRef]

64. Heredia, N.; García, S. Animals as sources of food-borne pathogens: A review. Anim. Nutr. 2018, 4, 250-255. [CrossRef] [PubMed]

65. Browne, A.J.; Hamadani, B.H.K.; Kumaran, E.; Rao, P.; Longbottom, J.; Harriss, E.; Moore, C.; Dunachie, S.; Basnyat, B.; Baker, S.; et al. Drug-resistant enteric fever worldwide, 1990 to 2018: A systematic review and meta-analysis. BMC Med. 2020, 18, 1. [CrossRef] [PubMed]

66. Xu, X.; Biswas, S.; Gu, G.; Elbediwi, M.; Li, Y.; Yue, M. Characterization of Multidrug Resistance Patterns of Emerging Salmonella enterica Serovar Rissen along the Food Chain in China. Antibiotics 2020, 9, 660. [CrossRef]

67. Elshaarawy, R.F.; Mustafa, F.H.; Sofy, A.R.; Hmed, A.A.; Janiak, C. A new synthetic antifouling coatings integrated novel aminothiazole-functionalized ionic liquids motifs with enhanced antibacterial performance. J. Environ. Chem. Eng. 2019, 7, 102800. [CrossRef]

68. Michael, G.; Schwarz, S. Antimicrobial resistance in zoonotic nontyphoidal Salmonella: An alarming trend? Clin. Microbiol. Infect. 2016, 22, 968-974. [CrossRef] [PubMed]

69. European Food Safety Authority; European Centre for Disease Prevention and Control. The European Union summary report on antimicrobial resistance in zoonotic and indicator bacteria from humans, animals and food in 2016. EFSA J. 2018, 16, e05182. [CrossRef]

70. Eng, S.-K.; Pusparajah, P.; Ab Mutalib, N.-S.; Ser, H.-L.; Chan, K.-G.; Lee, L.-H. Salmonella: A review on pathogenesis, epidemiology and antibiotic resistance. Front. Life Sci. 2015, 8, 284-293. [CrossRef]

71. Megahed, A.; Dougdoug, K.A.E.; Othman, B.; Lashin, S.; Ibrahim, M.; Sofy, A. A New Egyptian Satellite Strain of Cucumber Mosaic Cucumovirus. Int. J. Virol. 2012, 8, 240-257. [CrossRef]

72. Megahed, A.; El-Dougdou, K.A.; Othman, B.; Lashin, S.; Ibrahim, M.; Sofy, A. Induction of Resistance in Tomato Plants Against Tomato mosaic tobamovirus Using Beneficial Microbial Isolates. Pak. J. Biol. Sci. 2013, 16, 385-390. [CrossRef] [PubMed]

73. Stefanucci, A.; Amato, J.; Brancaccio, D.; Pagano, B.; Randazzo, A.; Santoro, F.; Mayol, L.; Learte-Aymamí, S.; Rodriguez, J.; Mascareñas, J.L.; et al. A novel $\beta$-hairpin peptide derived from the ARC repressor selectively interacts with the major groove of B-DNA. Bioorganic Chem. 2021, 112, 104836. [CrossRef]

74. Zare, N.; Makvandi, P.; Ashtari, B.; Rossi, F.; Motahari, A.; Perale, G. Progress in Conductive Polyaniline-Based Nanocomposites for Biomedical Applications: A Review. J. Med. Chem. 2020, 63, 1-22. [CrossRef] 
75. Zare, E.N.; Jamaledin, R.; Naserzadeh, P.; Afjeh-Dana, E.; Ashtari, B.; Hosseinzadeh, M.; Vecchione, R.; Wu, A.; Tay, F.R.; Borzacchiello, A.; et al. Metal-Based Nanostructures/PLGA Nanocomposites: Antimicrobial Activity, Cytotoxicity, and Their Biomedical Applications. ACS Appl. Mater. Interfaces 2019, 12, 3279-3300. [CrossRef]

76. Li, X.-H.; Lee, J.-H. Antibiofilm agents: A new perspective for antimicrobial strategy. J. Microbiol. 2017, 55, 753-766. [CrossRef]

77. Tasneem, U.; Yasin, N.; Nisa, I.; Shah, F.; Rasheed, U.; Momin, F.; Zaman, S.; Qasim, M. Biofilm producing bacteria: A serious threat to public health in developing countries. J. Food Sci. Nutr. 2018, 01, 25-31. [CrossRef]

78. Sharma, D.; Misba, L.; Khan, A.U. Antibiotics versus biofilm: An emerging battleground in microbial communities. Antimicrob. Resist. Infect. Control. 2019, 8, 76. [CrossRef]

79. Jung, L.-S.; Ding, T.; Ahn, J. Evaluation of lytic bacteriophages for control of multidrug-resistant Salmonella Typhimurium. Ann. Clin. Microbiol. Antimicrob. 2017, 16, 66. [CrossRef] [PubMed]

80. Evans, A.; Kavanagh, K.A. Evaluation of metal-based antimicrobial compounds for the treatment of bacterial pathogens. J. Med Microbiol. 2021, 70, 001363. [CrossRef]

81. Guenther, S.; Herzig, O.; Fieseler, L.; Klumpp, J.; Loessner, M.J. Biocontrol of Salmonella Typhimurium in RTE foods with the virulent bacteriophage FO1-E2. Int. J. Food Microbiol. 2012, 154, 66-72. [CrossRef] [PubMed]

82. Islam, M.; Zhou, Y.; Liang, L.; Nime, I.; Liu, K.; Yan, T.; Wang, X.; Li, J. Application of a Phage Cocktail for Control of Salmonella in Foods and Reducing Biofilms. Viruses 2019, 11, 841. [CrossRef] [PubMed]

83. Lu, T.K.; Koeris, M.S. The next generation of bacteriophage therapy. Curr. Opin. Microbiol. 2011, 14, 524-531. [CrossRef]

84. Chan, B.K.; Abedon, S.T. Phage Therapy Pharmacology. Adv. Appl. Microbiol. 2012, 78, 1-23. [CrossRef] [PubMed]

85. Sofy, A.R.; El Haliem, N.F.A.; Refaey, E.E.; Hmed, A.A. Polyvalent Phage CoNShP-3 as a Natural Antimicrobial Agent Showing Lytic and Antibiofilm Activities against Antibiotic-Resistant Coagulase-Negative Staphylococci Strains. Foods $2020,9,673$. [CrossRef]

86. Sofy, A.R.; Aboseidah, A.A.; El-Morsi, E.-S.; Azmy, H.A.; Hmed, A.A. Evaluation of Antibacterial and Antibiofilm Activity of New Antimicrobials as an Urgent Need to Counteract Stubborn Multidrug-resistant Bacteria. J. Pure Appl. Microbiol. 2020, 14, 595-608. [CrossRef]

87. El-Sheshtawy, H.S.; Sofy, M.R.; Ghareeb, D.A.; Yacout, G.A.; Eldemellawy, M.A.; Ibrahim, B.M. Eco-friendly polyurethane acrylate (PUA)/natural filler-based composite as an antifouling product for marine coating. Appl. Microbiol. Biotechnol. 2021, 105, 7023-7034. [CrossRef]

88. Bielke, L.; Higgins, S.; Donoghue, A.; Hargis, B.M. Salmonella Host Range of Bacteriophages That Infect Multiple Genera. Poult. Sci. 2007, 86, 2536-2540. [CrossRef] [PubMed]

89. Pires, D.P.; Oliveira, H.; Melo, L.; Sillankorva, S.; Azeredo, J. Bacteriophage-encoded depolymerases: Their diversity and biotechnological applications. Appl. Microbiol. Biotechnol. 2016, 100, 2141-2151. [CrossRef]

90. O'Flynn, G.; Coffey, A.; Fitzgerald, G.; Ross, R. The newly isolated lytic bacteriophages st104a and st104b are highly virulent against Salmonella enterica. J. Appl. Microbiol. 2006, 101, 251-259. [CrossRef]

91. Sofy, A.R.; Mahfouze, S.A.; El-Enany, M.A. Isozyme markers for response of wild potato species to potato spindle tuber viroid egyptian isolate. World Appl. Sci. J. 2013, 27, 1010-1022.

92. Ahmadi, H.; Radford, D.; Kropinski, A.M.; Lim, L.-T.; Balamurugan, S. Thermal-Stability and Reconstitution Ability of Listeria Phages P100 and A511. Front. Microbiol. 2017, 8, 2375. [CrossRef] [PubMed]

93. Sommer, J.; Trautner, C.; Witte, A.K.; Fister, S.; Schoder, D.; Rossmanith, P.; Mester, P.-J. Don't Shut the Stable Door after the Phage Has Bolted-The Importance of Bacteriophage Inactivation in Food Environments. Viruses 2019, 11, 468. [CrossRef]

94. Jepson, C.D.; March, J.B. Bacteriophage lambda is a highly stable DNA vaccine delivery vehicle. Vaccine 2004, $22,2413-2419$. [CrossRef] [PubMed]

95. Magin, V.; Garrec, N.; Andrés, Y. Selection of Bacteriophages to Control In Vitro 24 h Old Biofilm of Pseudomonas aeruginosa Isolated from Drinking and Thermal Water. Viruses 2019, 11, 749. [CrossRef]

96. Sofy, A.; El-Dougdoug, N.; Refaey, E.; Dawoud, R.; Hmed, A. Characterization and Full Genome Sequence of Novel KPP-5 Lytic Phage against Klebsiella pneumoniae Responsible for Recalcitrant Infection. Biomedicines 2021, 9, 342. [CrossRef] [PubMed]

97. Sofy, M.R.; Aboseidah, A.A.; Heneidak, S.A.; Ahmed, H.R. ACC deaminase containing endophytic bacteria ameliorate salt stress in Pisum sativum through reduced oxidative damage and induction of antioxidative defense systems. Environ. Sci. Pollut. Res. 2021, 28, 40971-40991. [CrossRef] [PubMed]

98. Dorman, H.J.D; Deans, S.G. Antimicrobial agents from plants: Antibacterial activity of plant volatile oils. J. Appl. Microbiol. 2000, 88, 308-316. [CrossRef]

99. Landers, T.F.; Cohen, B.; Wittum, T.E.; Larson, E.L. A Review of Antibiotic Use in Food Animals: Perspective, Policy, and Potential. Public Health Rep. 2012, 127, 4-22. [CrossRef]

100. Lee, N.-K.; Paik, H.-D. Status, Antimicrobial Mechanism, and Regulation of Natural Preservatives in Livestock Food Systems. Food Sci. Anim. Resour. 2016, 36, 547-557. [CrossRef]

101. Juhaimi, F.A.L.; Ghafoor, K.; Özcan, M.M.; Jahurul, M.H.A.; Babiker, E.E.; Jinap, S.; Sahena, F.; Sharifudin, M.S.; Zaidul, I.S.M. Effect of various food processing and handling methods on preservation of natural antioxidants in fruits and vegetables. J. Food Sci. Technol. 2018, 55, 3872-3880. [CrossRef] [PubMed]

102. Harper, D.R.; Parracho, H.M.R.T.; Walker, J.; Sharp, R.J.; Hughes, G.; Werthén, M.; Lehman, S.M.; Morales, S. Bacteriophages and Biofilms. Antibiotics 2014, 3, 270-284. [CrossRef] 
103. Pennone, V.; Sanz-Gaitero, M.; O'Connor, P.; Coffey, A.; Jordan, K.; Van Raaij, M.J.; McAuliffe, O.; Gaitero, S.-; Connor, O.; Raaij, V. Inhibition of L. monocytogenes Biofilm Formation by the Amidase Domain of the Phage vB_LmoS_293 Endolysin. Viruses 2019, 11, 722. [CrossRef] [PubMed]

104. Huang, C.; Virk, S.M.; Shi, J.; Zhou, Y.; Willias, S.P.; Morsy, M.K.; Abdelnabby, H.E.; Liu, J.; Wang, X.; Li, J. Isolation, Characterization, and Application of Bacteriophage LPSE1 against Salmonella enterica in Ready to Eat (RTE) Foods. Front. Microbiol. 2018, 9, 1046. [CrossRef] [PubMed]

105. Goodridge, L.D.; Bisha, B. Phage-based biocontrol strategies to reduce foodborne pathogens in foods. Bacteriophage 2011, 1, 130-137. [CrossRef]

106. Grant, A.; Hashem, F.; Parveen, S. Salmonella and Campylobacter: Antimicrobial resistance and bacteriophage control in poultry. Food Microbiol. 2016, 53, 104-109. [CrossRef]

107. Osvaldo, L.O.P.C.; Nohelia, C.D.C.; Karina, R.; Bal, C.C.O.; López-Cuevas, O.; Campo, N.C.-D.; Ramírez, K.; Chaidez, C. Biocontrol of Salmonella Typhimurium growth in tomato surface by bacteriophage P22. Afr. J. Microbiol. Res. 2016, 10, 528-534. [CrossRef] 